نشريه تحقيقات كاربردى علوم جغرافيايى، سال بيست و يكم، شماره •9، بهار . .

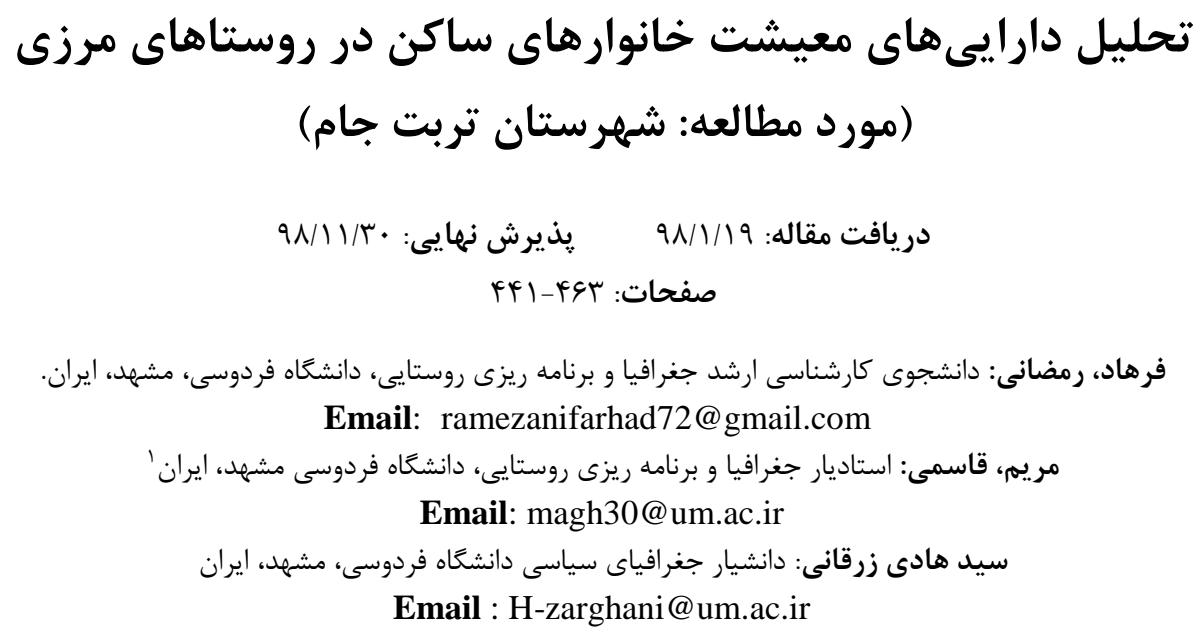

جكيده

امروزه در جارجوب توسعه پايدار روستايى نياز به اصلاح الكوهاى معيشتى سنتى و انطباق آن با الكوهاى

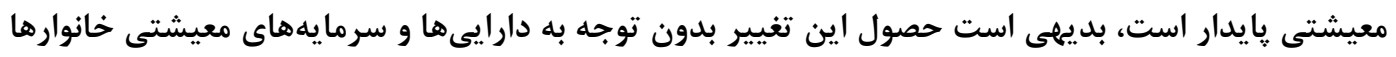
ممكن نيست. دارايى هاى معيشتى شامل انواع سرمايههاى طبيعى، فيزيكى، انسانى، اجتماعى و مالى است استى كهائ

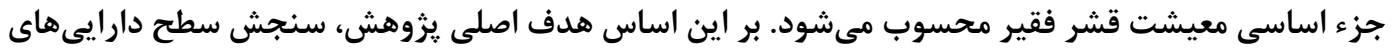

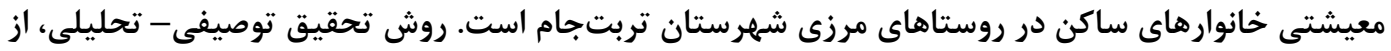

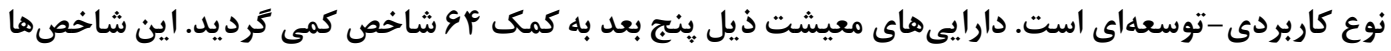

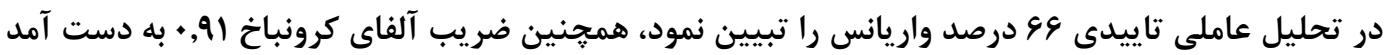

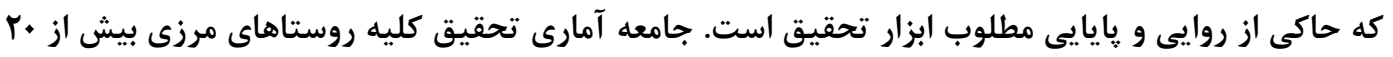

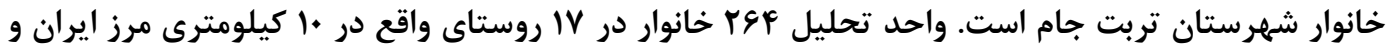

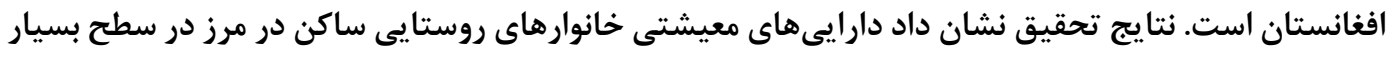

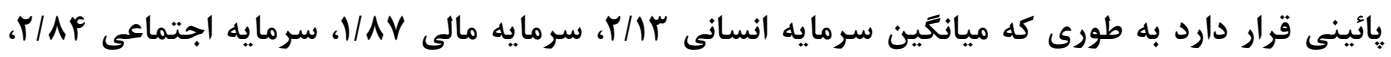

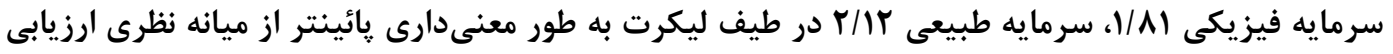

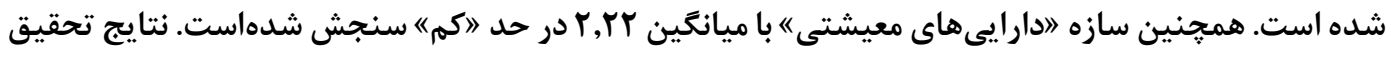

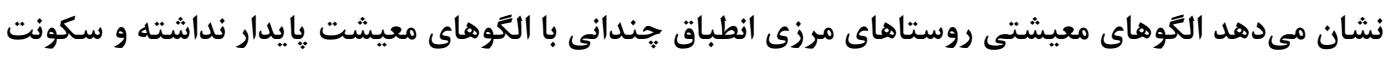

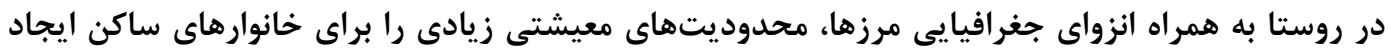

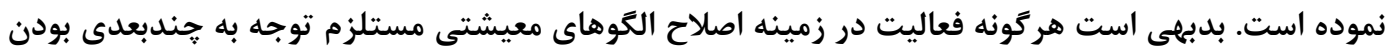
معيشت مىباشد. كليد وازَّان: دارايى هاى معيشتى، روستاهاى مرزى، شهرستان تربت جام، خانوارهاى روستايى، پايدارى معيشت 1. نويسنده مسئول: مشهي، دانشكاه فردوسى ، دانشكده برنامهريزى و علوم محيطى، كروه جغرافيا و برنامه ريزى روستايى 
روستاهاى مرزى از نقاط حساس و استراتزيك كشور به شمار مىروند كه از جهات مختلف (اقتصادى، اجتماعى،

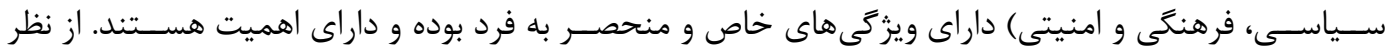

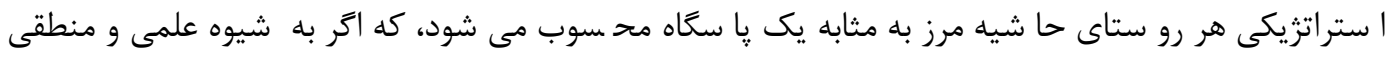

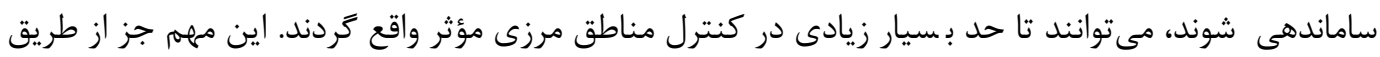

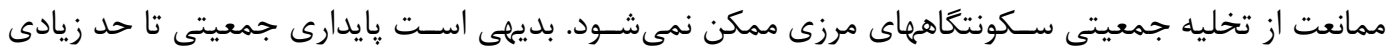

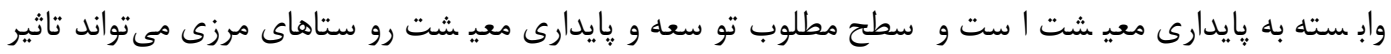

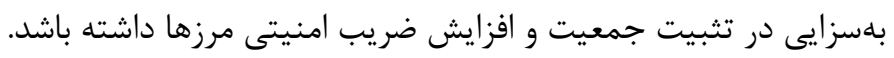

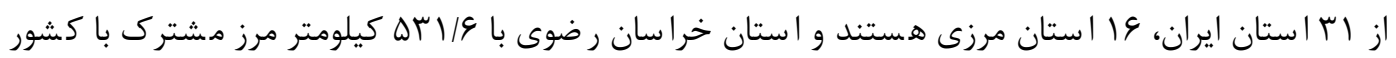

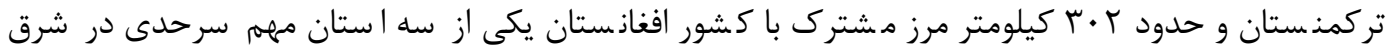

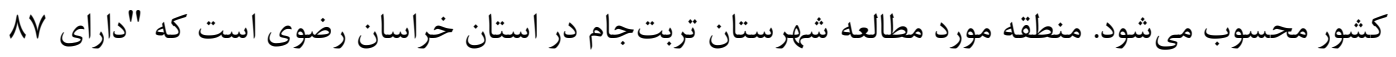
كيلومتر خط مرزى با كشور افغانستان است"(قدمعاهى و همكاران،

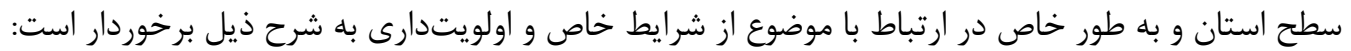

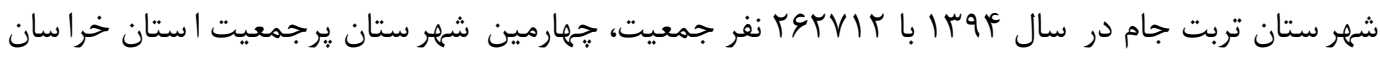

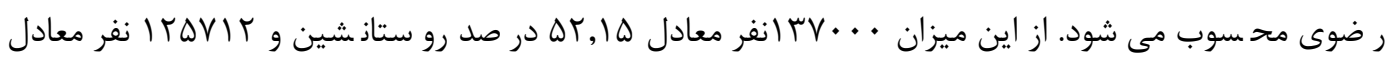

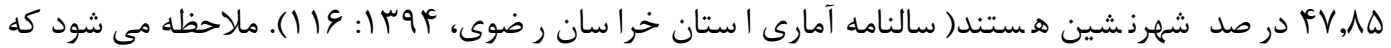
جمعيت روستانشين بر جمعيت شهرنشين در اين شهرستان غلبه دارد.

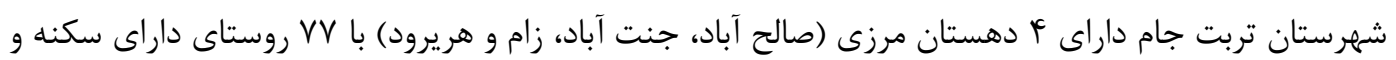

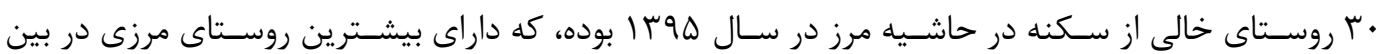
شهرستان هاى مرزى استان است.

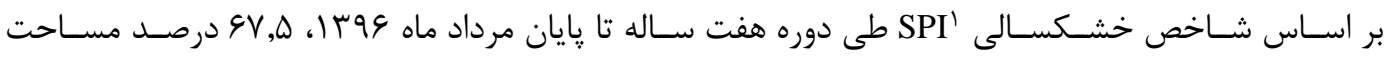

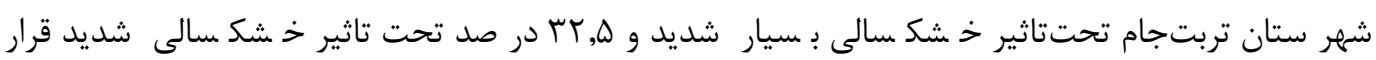

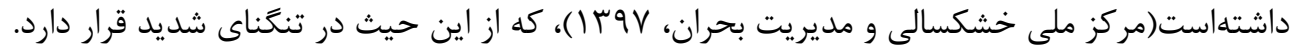

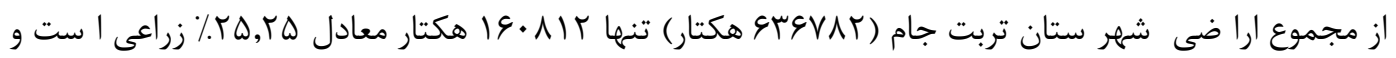

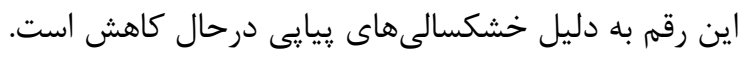

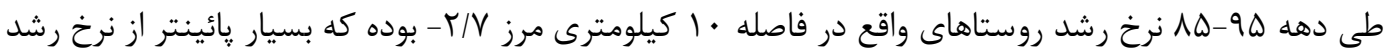

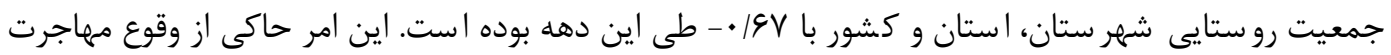

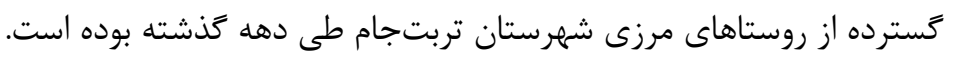

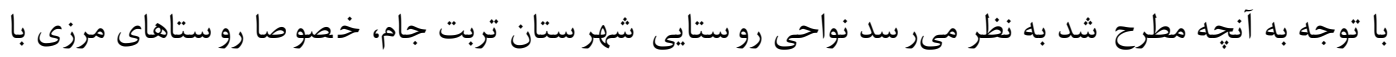

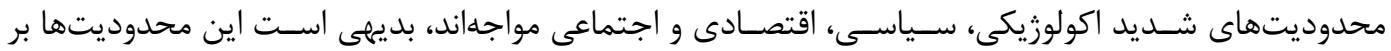


محدوديت معيشت خانورهاى رو ستايى تاثير كذار بوده است. عدم وجود شرايط طبيعى منا سب در شهر ستان

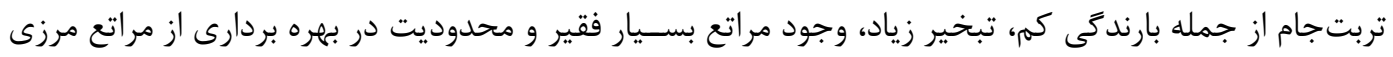

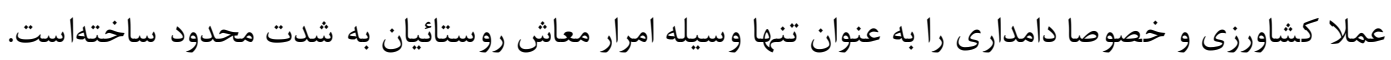

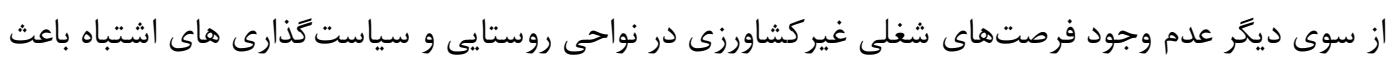

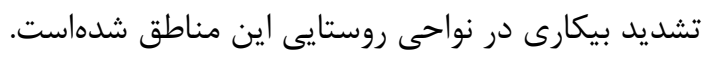

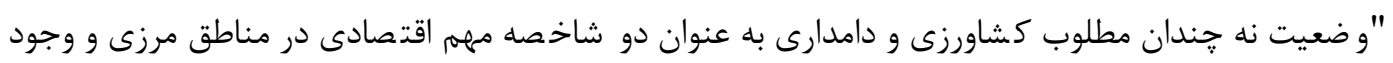

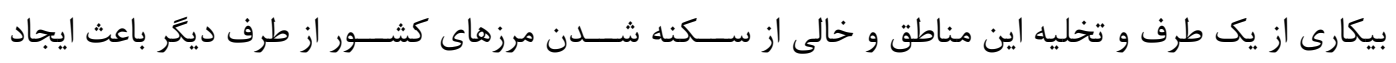

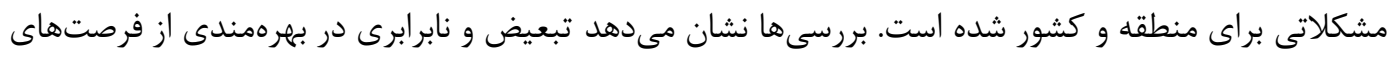

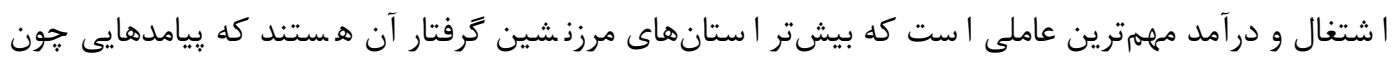

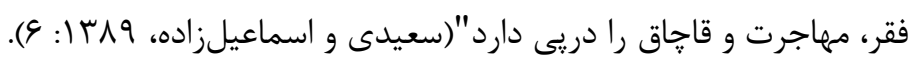

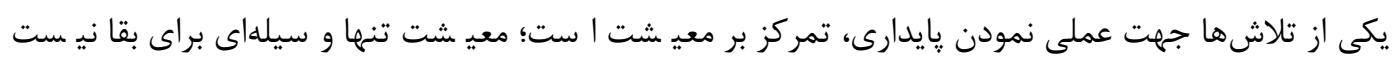

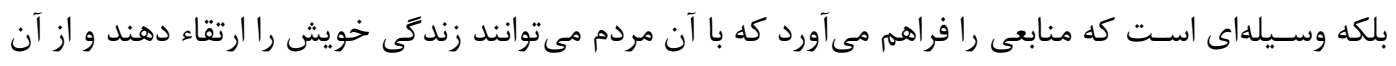

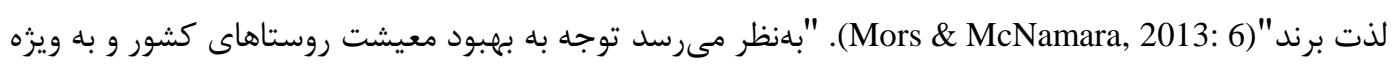

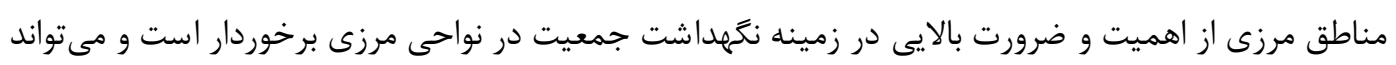

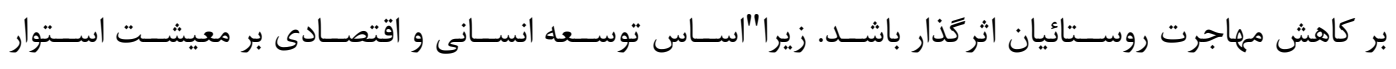

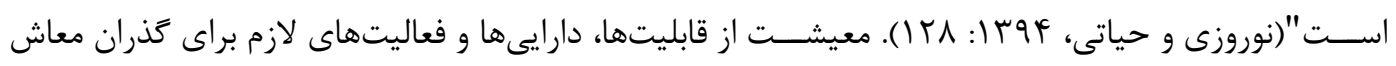

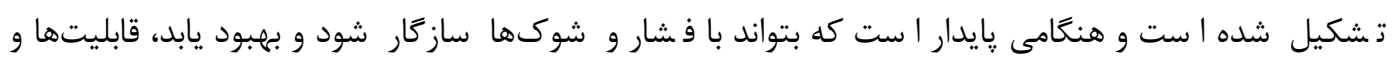

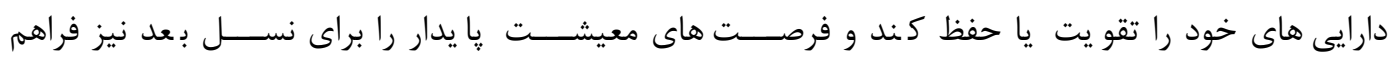

آورد"(6) : (Chambers \& Conway, 1991).

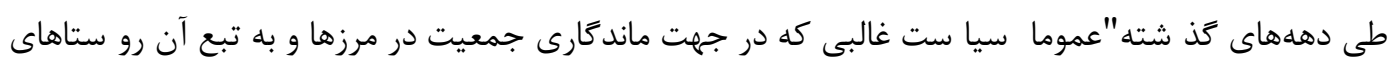

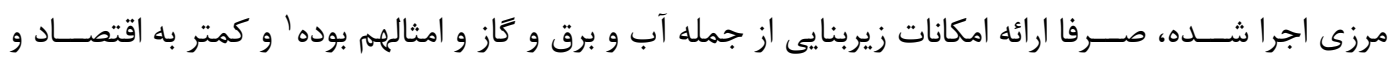

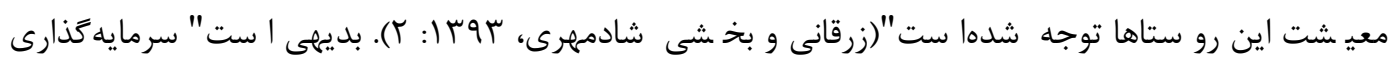

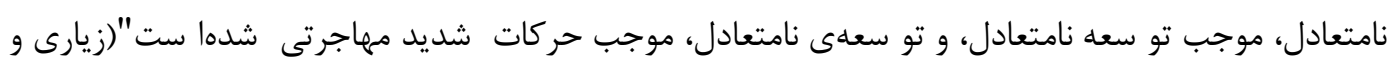

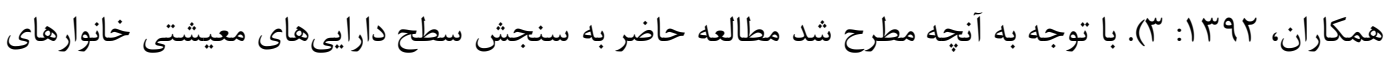

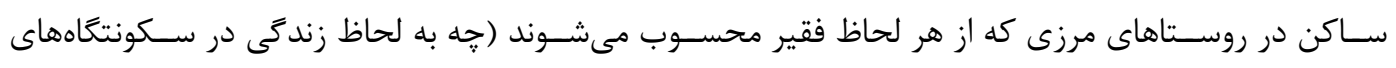

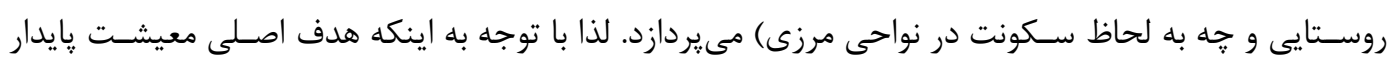

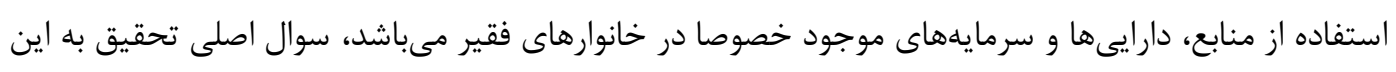

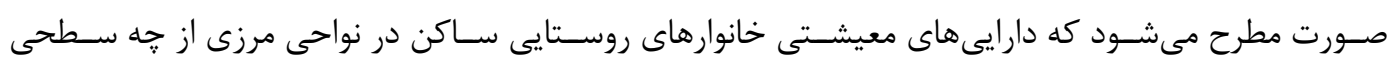
برخوردار است؟ مورت مطرح

\section{يبشينه تحقيق}


بررسى يِيشينه تحقيق نشان مى دهد طى دهه اخير"رويكرد معيشت يايدار، بر تفكرى جامع و منسجم دربارهى

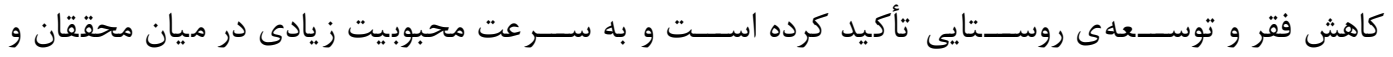

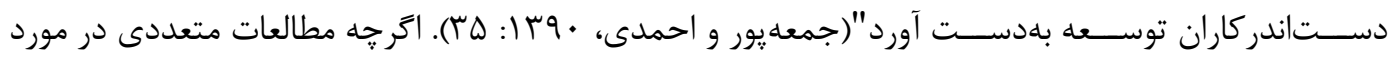

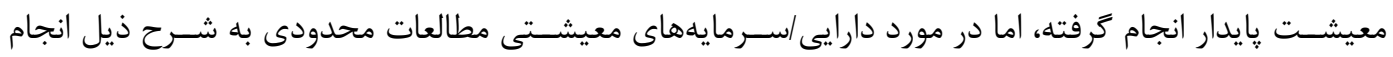
يذيرفته است.

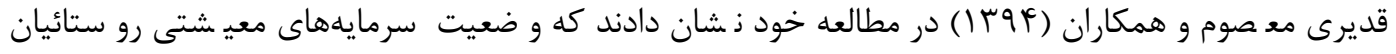

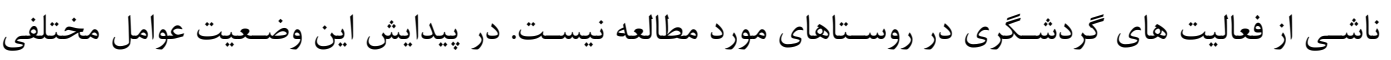

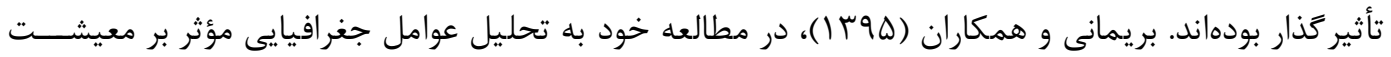

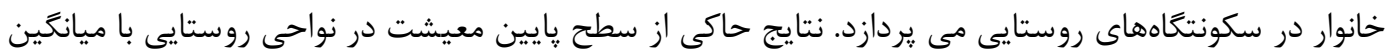

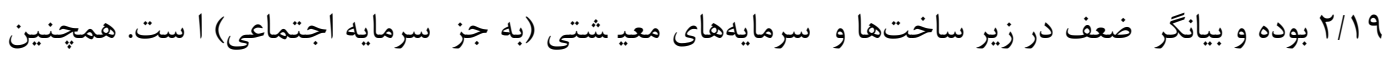

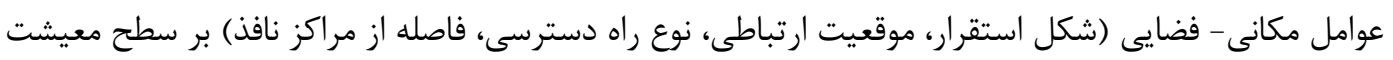

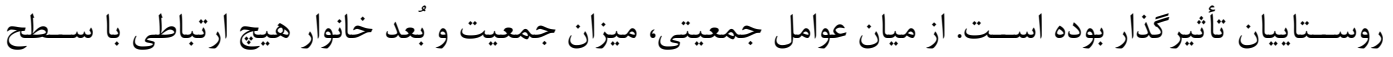
معيشت روستايى ندارند؛ اما نسبت باسوادى و نسبت مهاجرت به ترتيب رابطؤ مستقيم و معكوس معنادارى رانيا رانيا

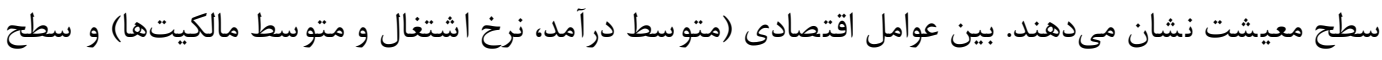

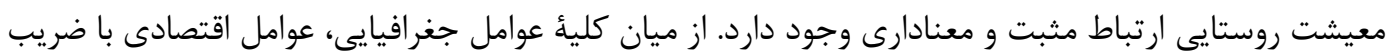

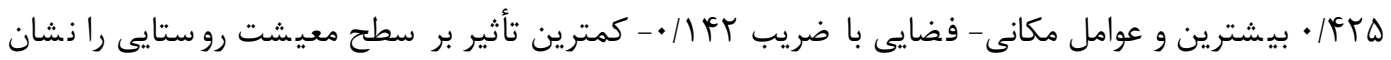

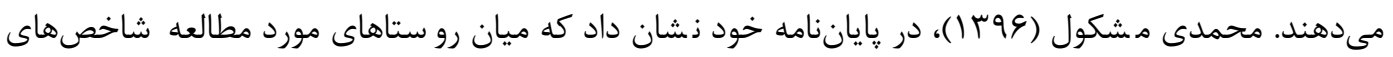

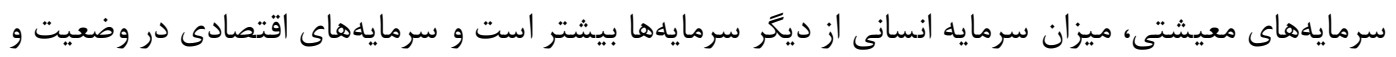

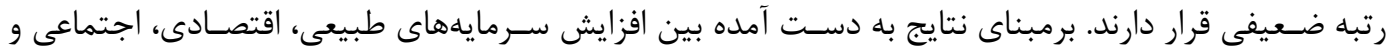

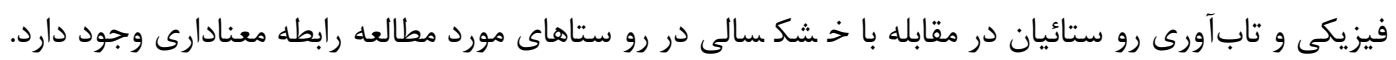

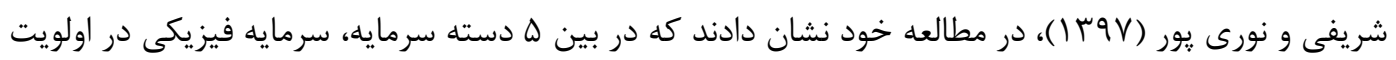

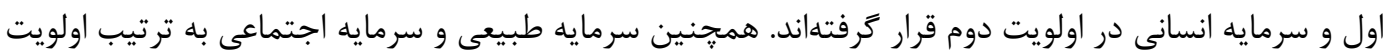

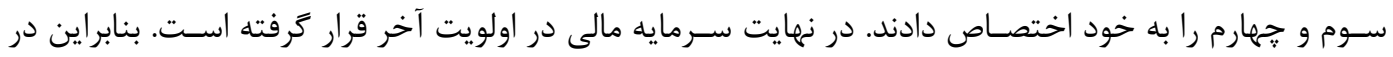

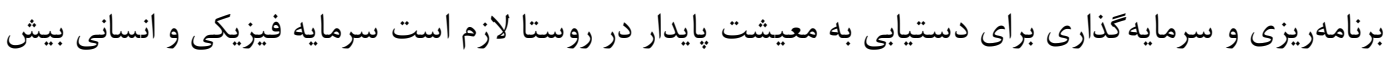

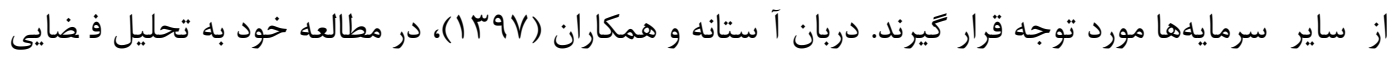

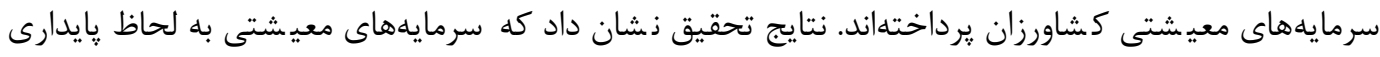

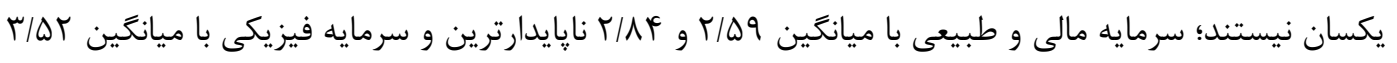

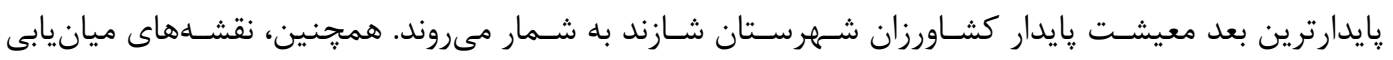

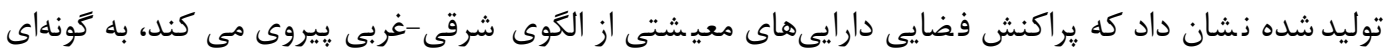

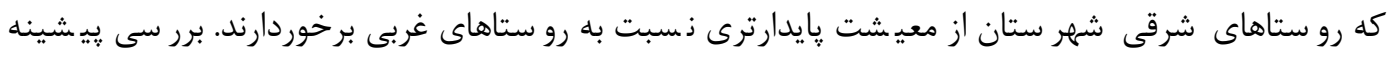

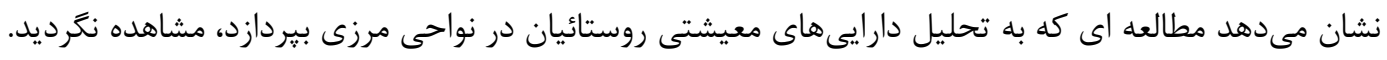




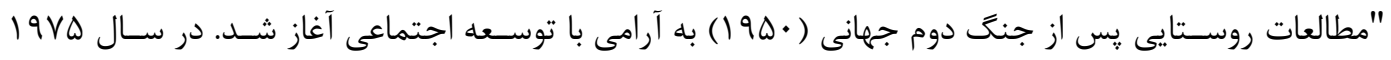

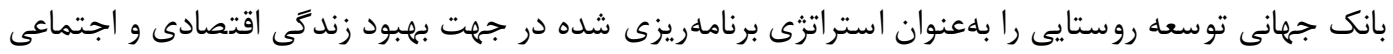

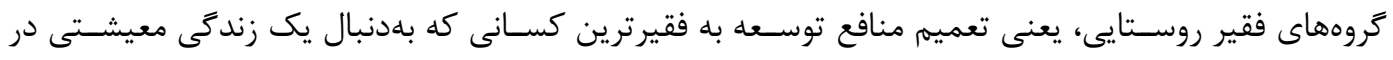

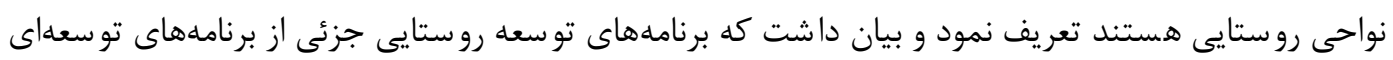
هر كشور است"(يايلى و ابراهيمى، عیى ا: اله). جدول (1).

جدول (1). سير تحول نظر يههاى توسعهى بايدار و توسعهى روستايى

\begin{tabular}{|c|c|c|}
\hline توسعلى روستايى & توسعه & ترتيب زمانى \\
\hline مدل جمعيت و توسعه & مدرنيزاسيون & $199 \cdot-190 \cdot$ \\
\hline اقتصاد سياسى تغييرات ارضى & نظريه وابستكى & $197 \cdot-199$. \\
\hline توسعلى كشاورزى & توسعلى جايكزين & $191 \cdot d 80$ \\
\hline رويكرد معيشت پايدار (SLA) & توسعهى يايدار & . 199 - امروز \\
\hline
\end{tabular}

مأخذ: Shen, 2009: 51 مأر

راهبرد معيشت پايدار به عنوان يكى از رويكردهاى نظريهى توسعهى يايدار، راهبرد جديدى است كه در مقولهى

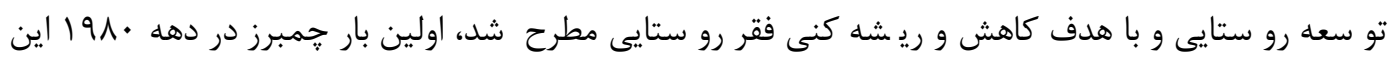

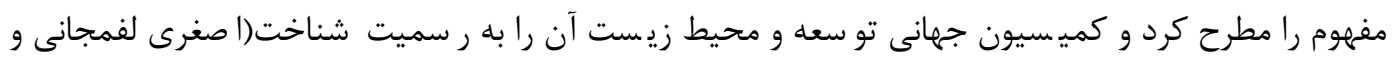

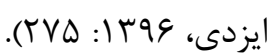

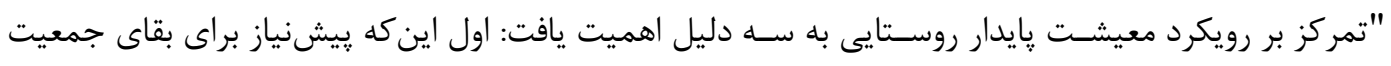

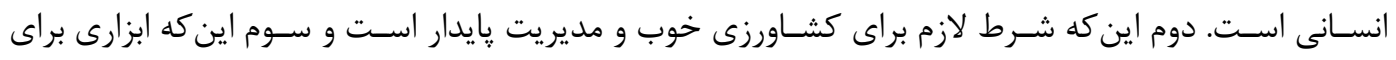

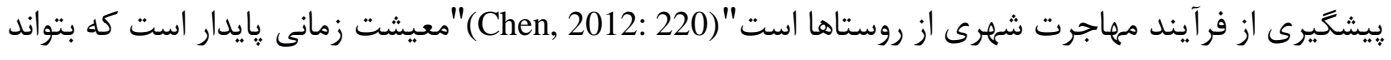

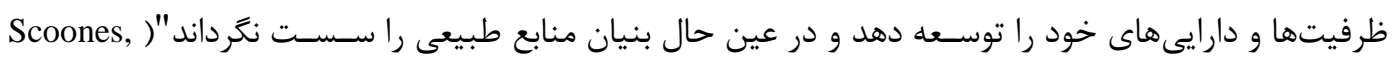

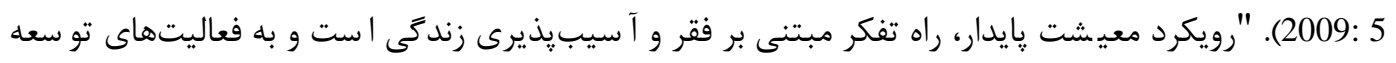

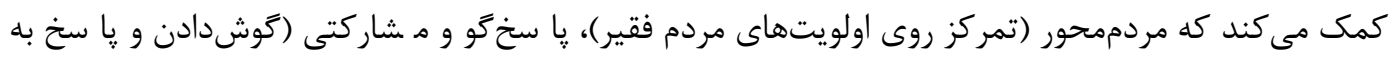

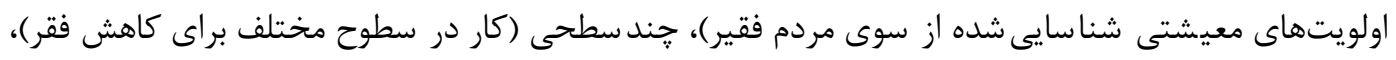

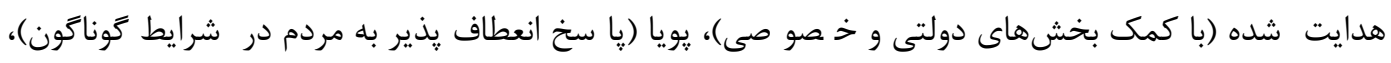

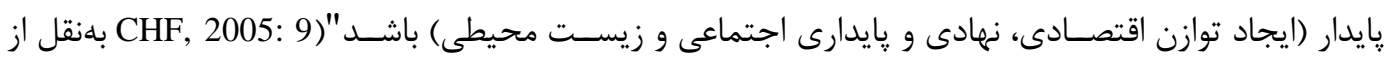

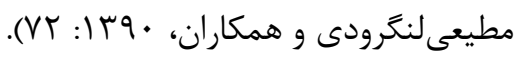

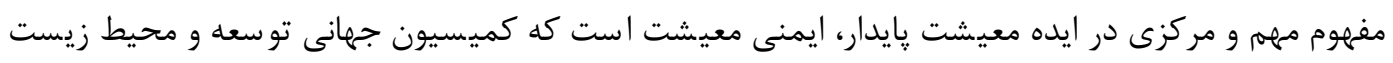

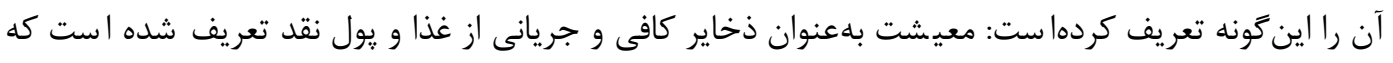

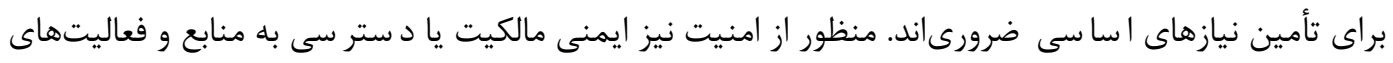

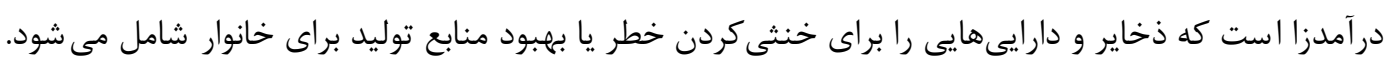

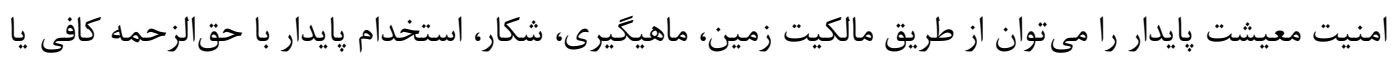

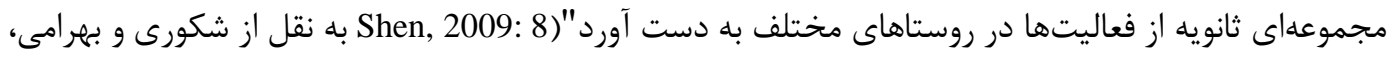




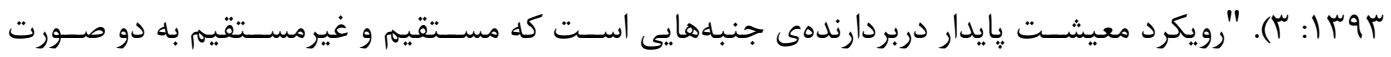

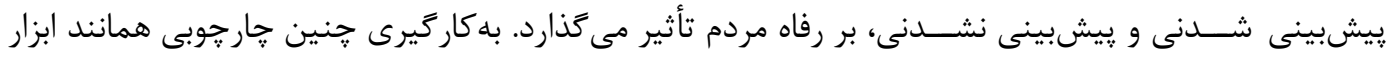

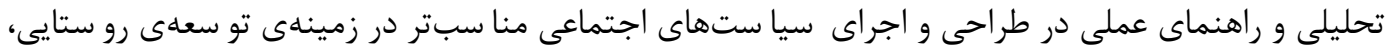

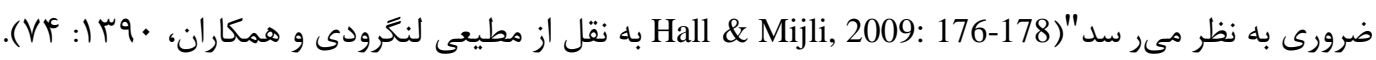

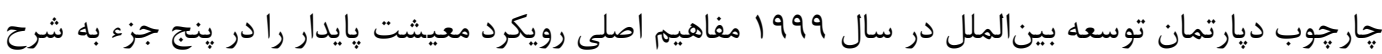
زير تبيين مى نمايد"(Shen, 2009: 11): دارايى ها: دارايىهاى معيشتى از انواع سرمايههاى طبيعى، فيزيكى، انسانى، اجتماعى و مالى تشكيل شدهاند و جزء اساسى معيشت قشر فقير هستند.

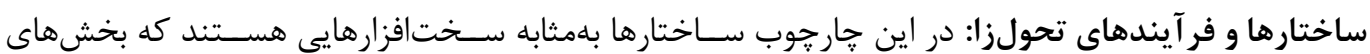

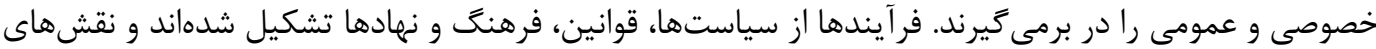
مهمى را در شكل دادن به دارايىها و نتايج معيشتى در درون سيستم معيشت ايفا معى كنند.

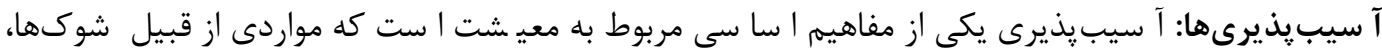

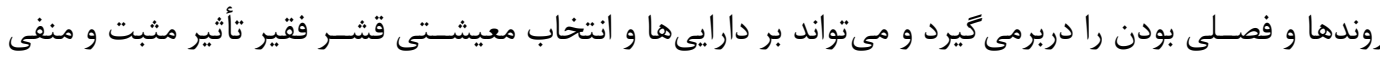
داشته باشد.

نتايج(ييامدها): نتايج، موفقيتها و هدفهايى براى ارزيابى معيشت هستند كه استراتزىهاى معيشتى از طريق

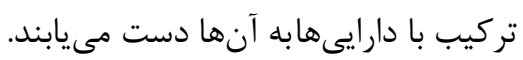
استراتزىها: فعاليتهايى هستند كه براى بقاى معيشتى به كار كرفته مىشوند"(توكلى و همكاران، هوس إ: 94).

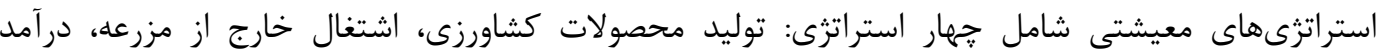

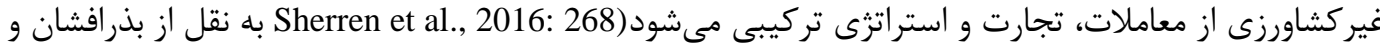

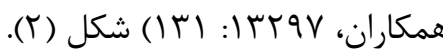

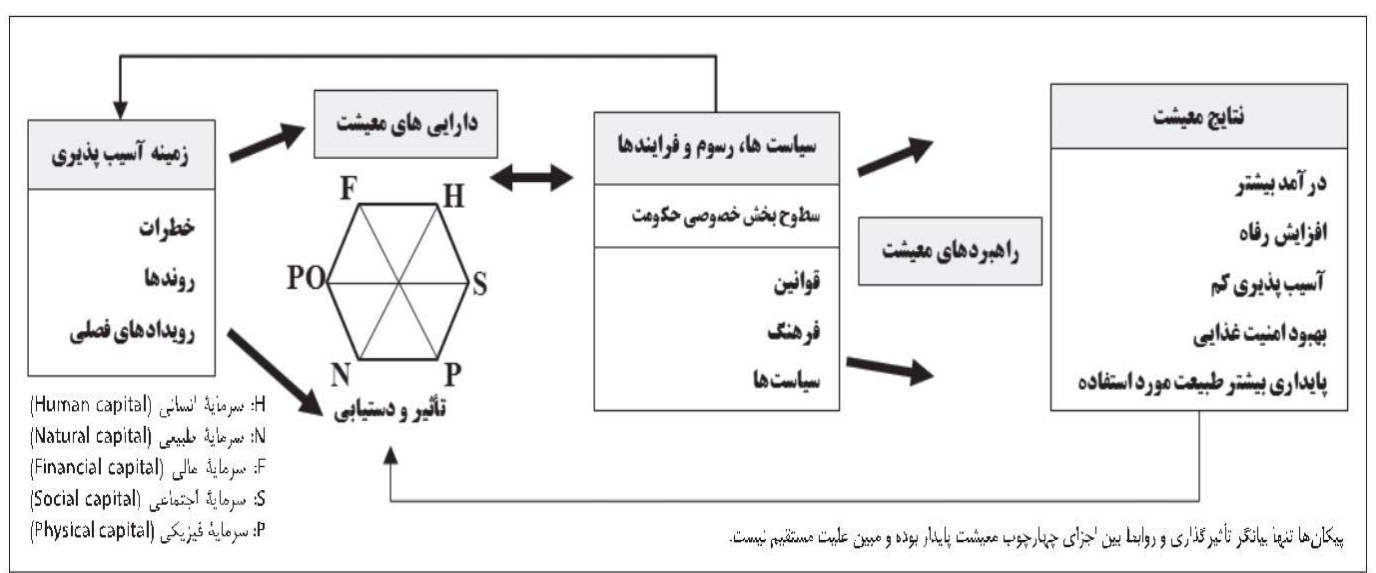

شكل (Y). جار جوب معيشت پايدار

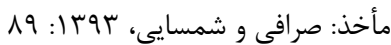




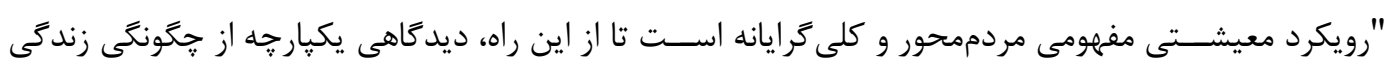

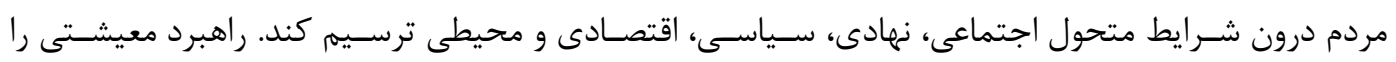

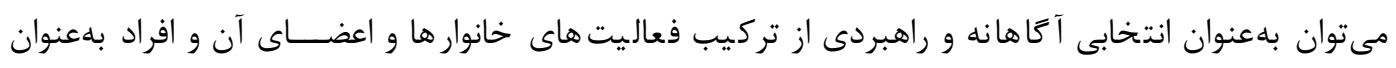

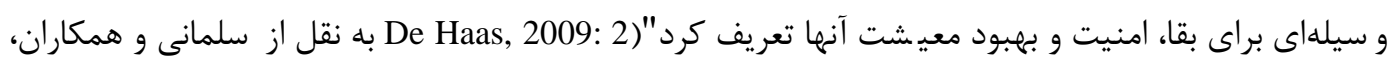

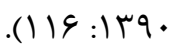

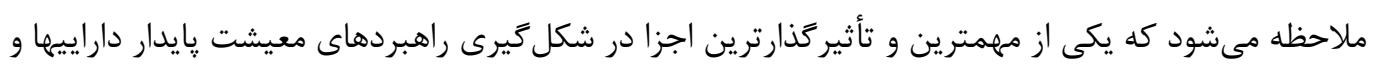

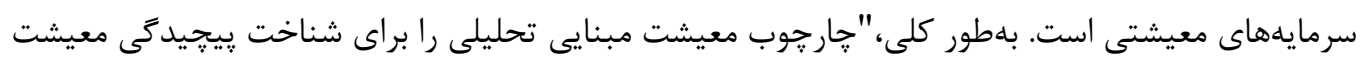

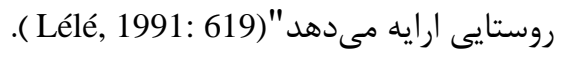

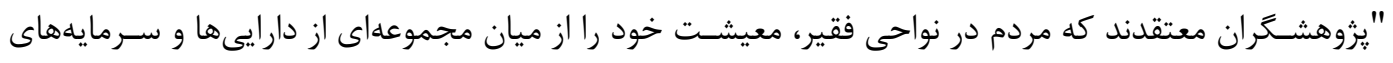

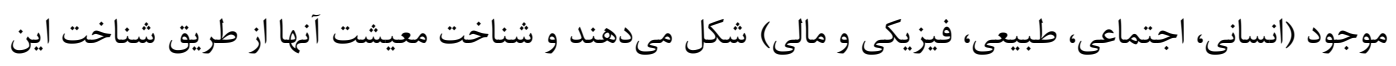

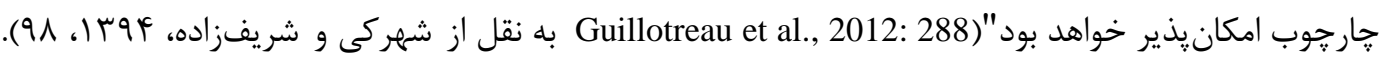

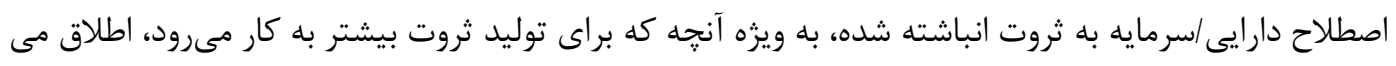

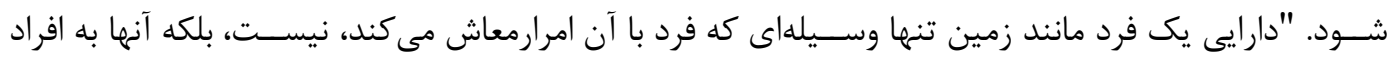

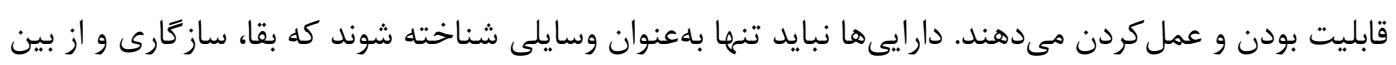

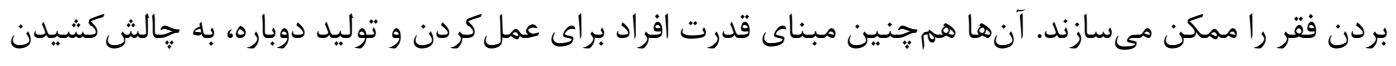

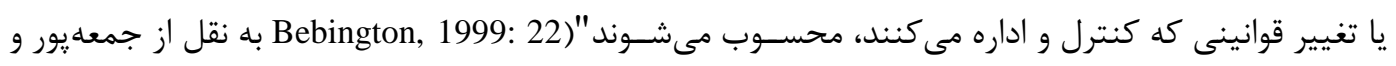

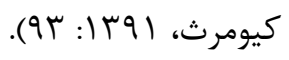

الف- سرمايهى انسانى': "از نظر بيكرَ سرمايه انسانى دارايىهاى ذاتى و قابل اكتساب يكى فرد مى باشد كه

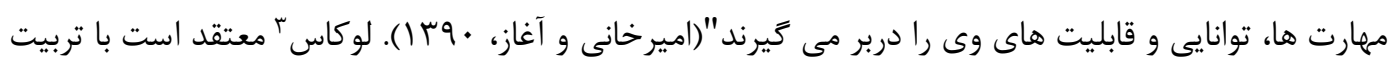

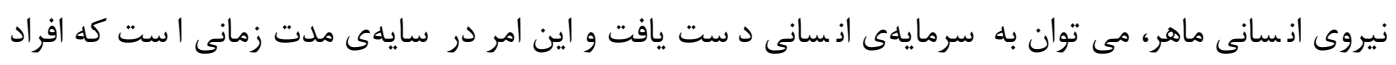

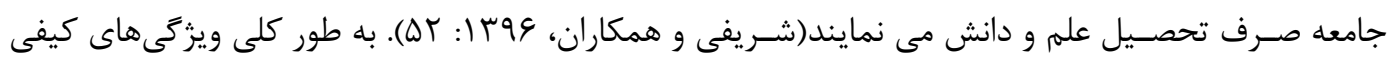

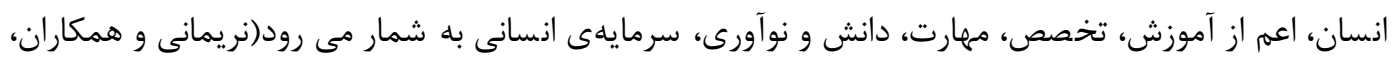

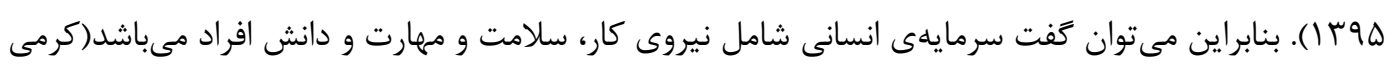

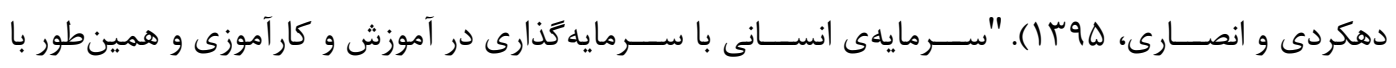

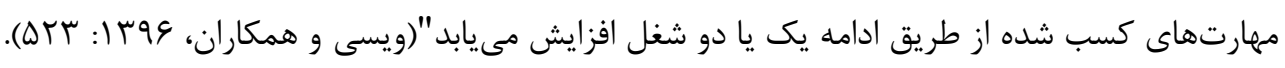

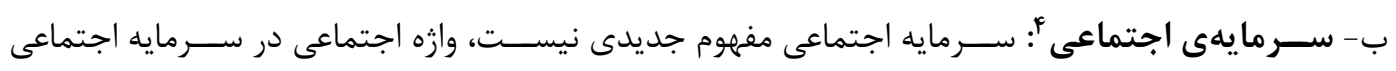

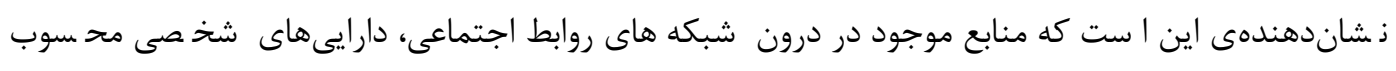

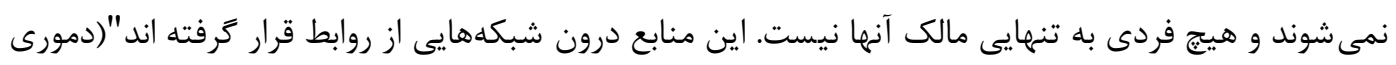

1. Human Capital

r. Baker

$r$. Lucas

ץ. Social Capital 


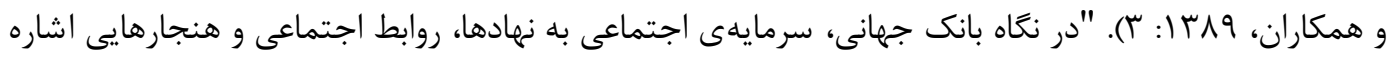
دارد كه كميت و كيفيت تعاملات اجتماعى يك جامعه را شـكل مى دهدد" (دارا،

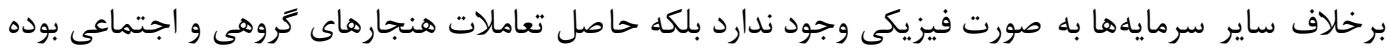

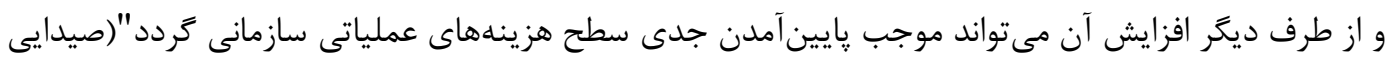

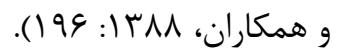

״- سرمايهى طبيعى': "سرمايهى طبيعى به آن دسته از منابع طبيعى و خدمات يشتيبان اكولوزيكى (به طور مثال جرخهى آب و مواد غذايى، حفاظت از فرسايش) كه براى معيشت مفيد هستند، اطلاق مى شعود. سرمايهى

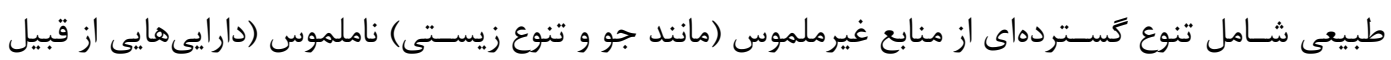

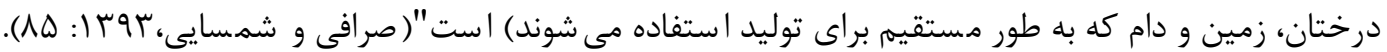

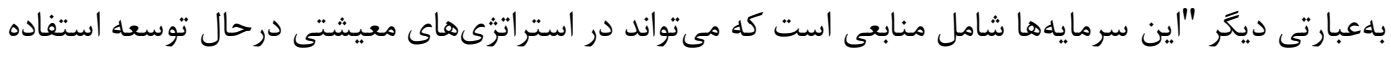

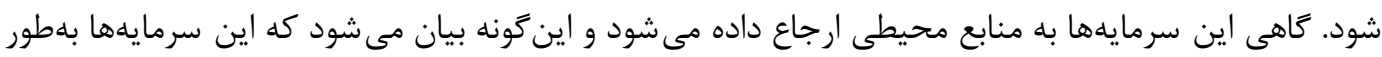
مشترك محيط را تشكيل مى دهند" (Frank, 1999: 32).

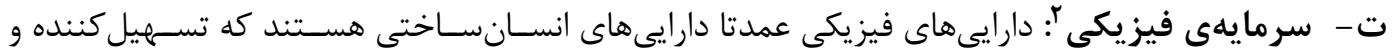

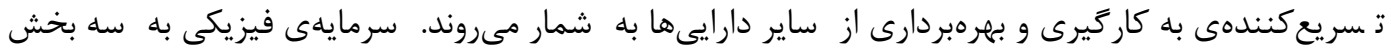

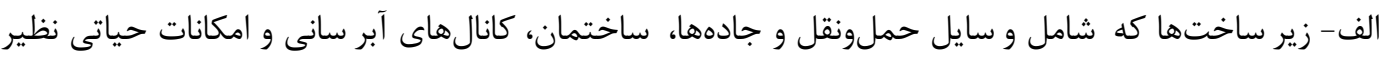

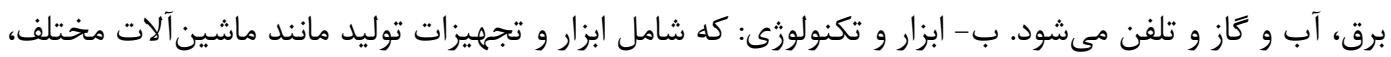

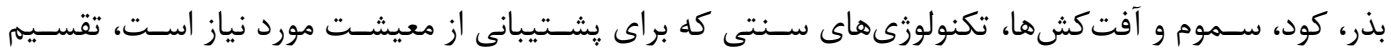

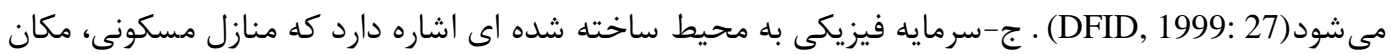

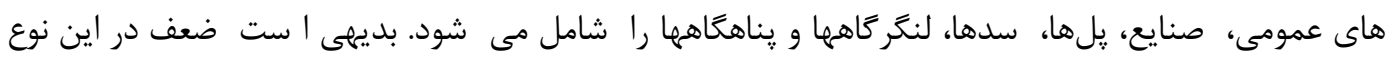
سرمايه مى تواند اثرات منفى بر توان و ظرفيت ساير سرمايههاى معيشتى دارد. بهايه باور ياتنام سرمايه فيزيكى،

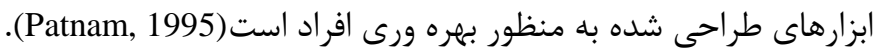

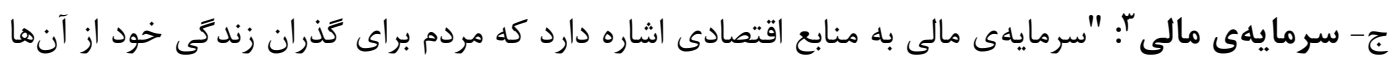

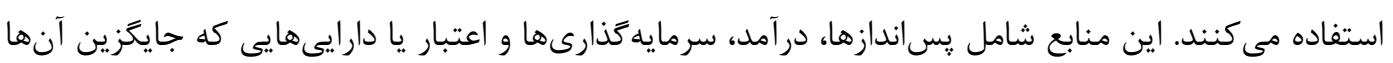

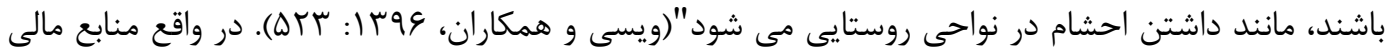
براى حفظ يا بهترشدن معيشت افراد در دسترس هستند و از ابعاد كوناكون نوع و ميزان و ماهيت، معيشت

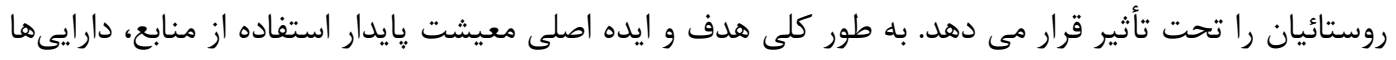

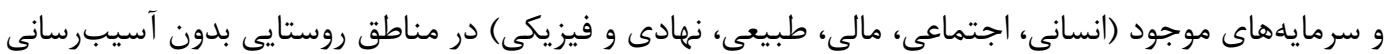

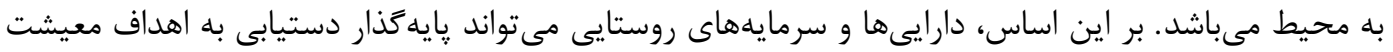

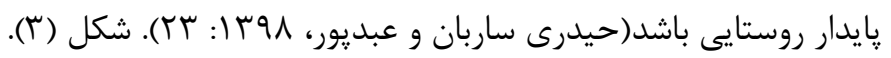

\footnotetext{
1. Natural Capital

r. Physical Capital

r. Financial Capital
} 


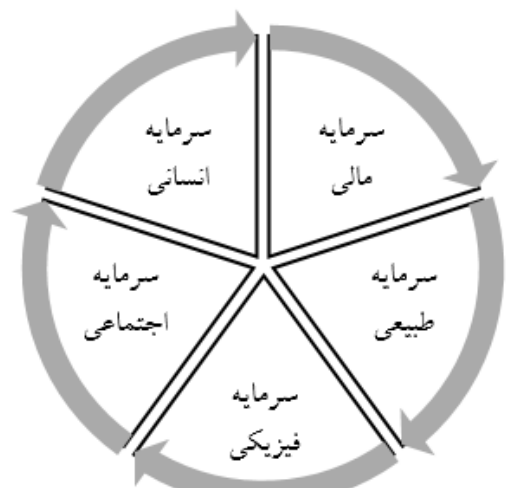

شكل (r). انواع دارايى هاى معيشتى خانوارهاى روستايى

روش تحقيق

يزوهش حاضــر از لحاظ هدف، كاربردى و نوع روش توصــيفى تحليلى مى باشــــ. جامعه آمارى تحقيق كليه

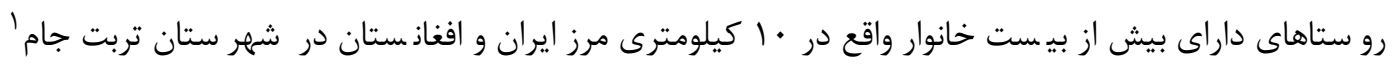
مى با شد. اين رو ستاها در f دها ستان مرزى جنت آباد، صالح آباد، زام و هريرود يراكنده اند. در مجموع تعداد

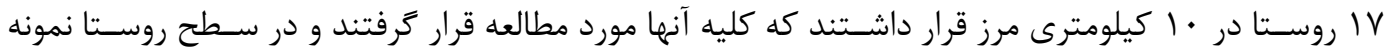
كيرى به عمل نيامد. واحد تحليل خانوارهاى روستايى ساكن در روستاهاى مناطق مرزى شهرستان بوده است و يرسـشــامه خانوار به كمك سـريرسـتان خانوارهاى روسـتايى سـاكن در روسـتاهاى مرزى تكميل شــــ حجم

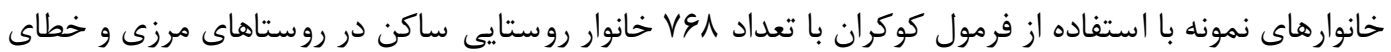

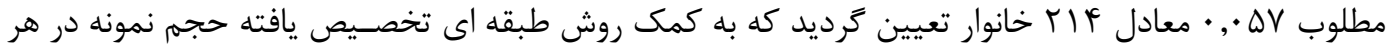
روستا به شرح جدول زير تعيين گرديد. جدول (؟).

جدول (r). روستاهاى واقع در محدوده ده كيلومترى مرز شهرستان تربت جام (هوسו)

\begin{tabular}{|c|c|c|c|c|c|}
\hline حجم خانوار نمونه & همعيت & خهانوار & نام روستا & نام دهستان & بخش \\
\hline 9 & 19 & re & ابراهيم باى & جنت آباد & \multirow{6}{*}{ صالح آباد } \\
\hline 19 & r. & VT & استاى سفلى & جنت اباد & \\
\hline 11 & trT & 99 & يده موسى خان & جنت آباد & \\
\hline 19 & rqu & $\Delta 9$ & جشمه انجير & جنت آباد & \\
\hline 9 & 114 & rA & سقر خشمه سفلى & صالح آباد & \\
\hline 1. & $1 \Delta F$ & f. & سنَ آب & صالح آباد & \\
\hline
\end{tabular}

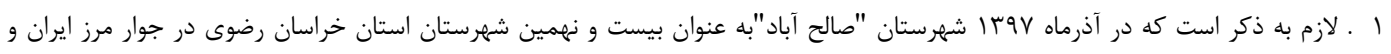

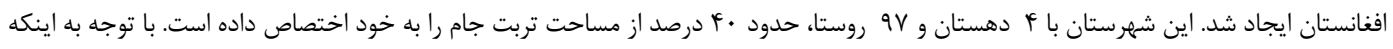

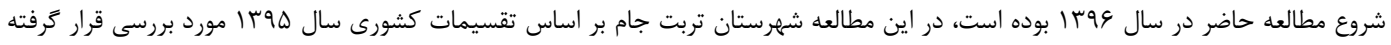

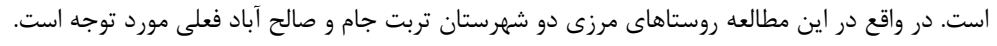




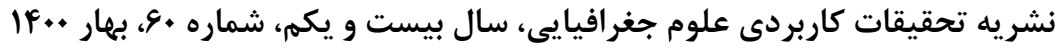

\begin{tabular}{|c|c|c|c|c|c|}
\hline 10 & $1 M$ & $\Delta \Lambda$ & سياه خوله & جنت آباد & \\
\hline If & THT & $\Delta r$ & كاريزك حاجى يسند & جنت آباد & \\
\hline 19 & TIV & 91 & كلاته باقى خان & جنت آباد & \\
\hline 9 & Irs & r & كلاته حميد & جنت آباد & \\
\hline 9 & $\Lambda \Delta$ & Tr & كلاته دهنو & جنت آباد & \\
\hline If & TFT & $\Delta r$ & كلاته صمد خان & جنت آباد & \\
\hline 9 & va & 19 & كنده سوخته & جنت آباد & \\
\hline 1. & 1.4 & re & عَرماسى & جنت آباد & \\
\hline 1. & IrT & rv & نصر آباد & جنت آباد & \\
\hline 11 & rTa & VE & ملوى عليا & زام & \multirow{2}{*}{ يايين جام } \\
\hline 9 & gt & $1 \pi$ & كاوجشمه & هريرود & \\
\hline TIF & rq৭. & $\vee \& \Lambda$ & - & - & - \\
\hline
\end{tabular}

مآخذ: مركز آمار ايران، سرشمارى عمومى نفوس و مسكن، هوب I.

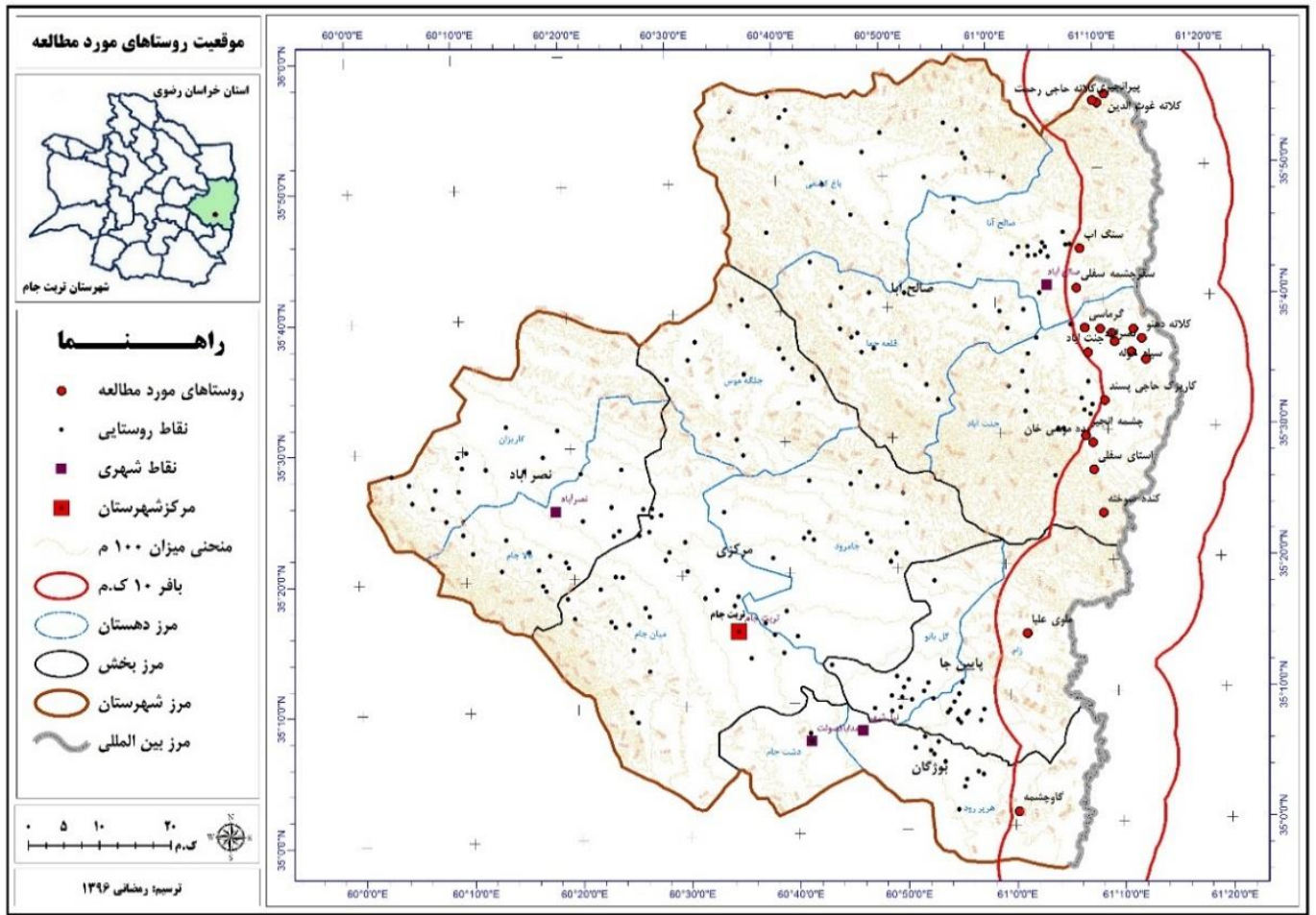

شكل (f). روستاهاى واقع در محدوده + ا كيلومترى مرز ايران و افغانستان در شهرستان تربت جام.

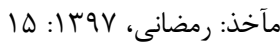

مولفه ها و متغيرهاى سازه دارايى معي شت به كمك مطالعات اكتشافى گ سترده (منابع ا سنادى و هـ صاحبه با

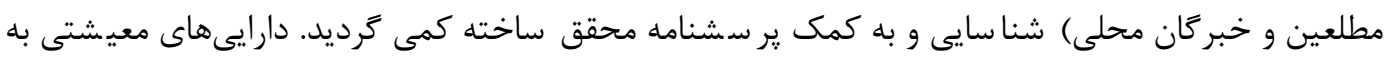

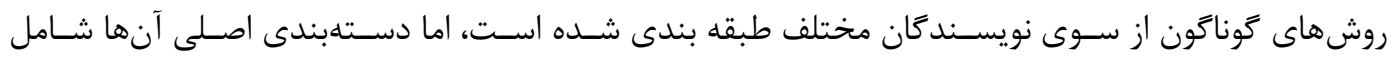


سرمايههاى انسانى، مالى، طبيعى، فيزيكى، اجتماعى مى باشد. در اين راستا در مطالعه حاضر عاع شاخص در ه

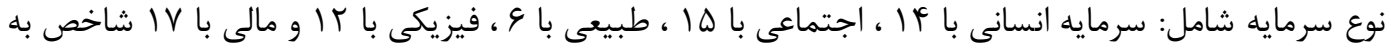
شرح جدول زير كمى گرديد. جدول (r).

جدول (r). تعريف عملياتى سازه دارايى هاى معيشتى خانوارهاى روستايى ساكن در نواحى مرزى

\begin{tabular}{|c|c|c|}
\hline شاخص & مولفه & بعد \\
\hline نيروى كار خانوادَى، ميزان بكاركيرى نيروى كار خارج از خانواده در فعاليتهاى كشاورزى و دامى و ... & كميت نيروى كار & \multirow{6}{*}{$\frac{3}{\frac{3}{3}}$} \\
\hline تعداد افراد باسواد در خانواده، تعداد افراد داراى تحصيلات دانشكاهى در خانواده & 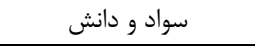 & \\
\hline وجود فرصت هاى شغلى متنوع براى جوانان (امكان اشتغال در مشاغل بخش خدانى خدمات، صنعت و و ...)، & توانايى تنوع بخشى منابع & \\
\hline 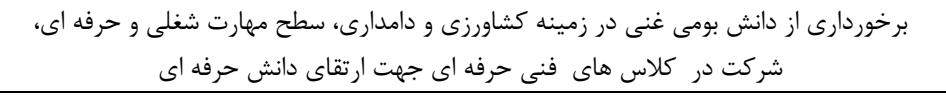 & 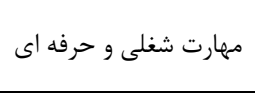 & \\
\hline 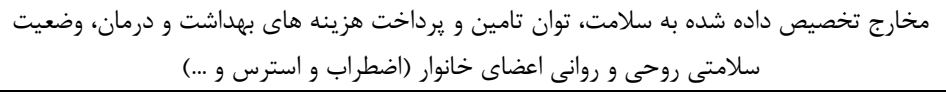 & بهداشت و درمان & \\
\hline 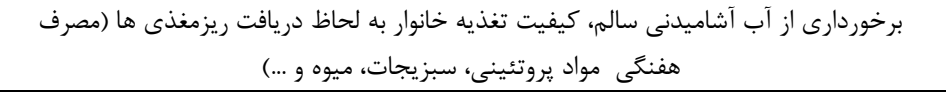 & كيفيت آب و تغذيه & \\
\hline ميزان درآمد ماهيانه خانوار، قدرت خريد خانوار، توان تامين هزينه هاى خانوار، توانايى كمك و & 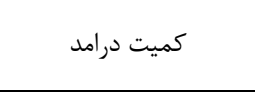 & \multirow{6}{*}{$\begin{array}{c}3 \\
3 \\
3 \\
3 \\
3 \\
3 \\
\frac{1}{3} \\
3 \\
3 \\
3 \\
3\end{array}$} \\
\hline سطح رفاه خانواده، برخوردارى از كالاهاى لوكس در منزل (يخحال سايد، مبلمان، تلويزيون LCD و & رفاه & \\
\hline برخوردارى از يس انداز كافى در مواجه با بحران ها (ازدواج فرزند، بيمارى و ...) & 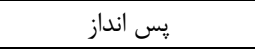 & \\
\hline 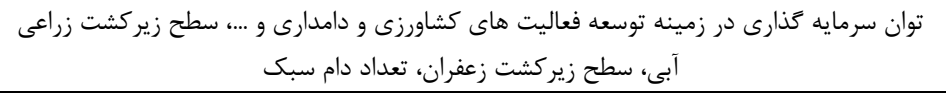 & 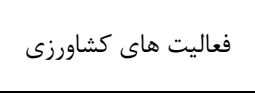 & \\
\hline برخوردارى از بيمه محصولات كشاورزى و دامى، دسترسى به اعتبارات بانكى با سود يائين، توانايى & 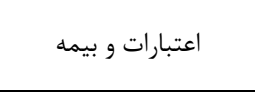 & \\
\hline 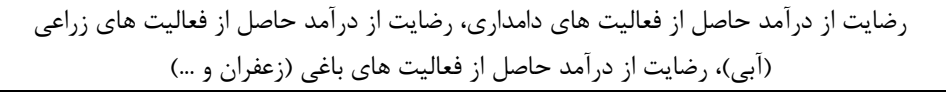 & 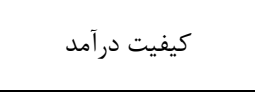 & \\
\hline مشاركت در امور خيريه روستا، همكارى در فعاليتهاى عمرانى روستا، مشاركت در امور مالى روستا & مشاركت & \multirow{5}{*}{ 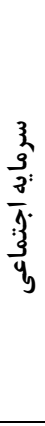 } \\
\hline 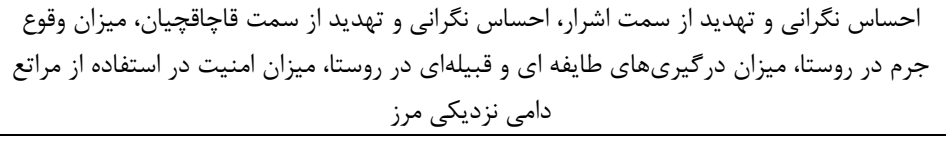 & 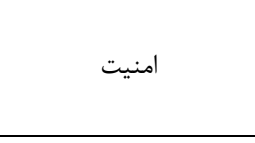 & \\
\hline 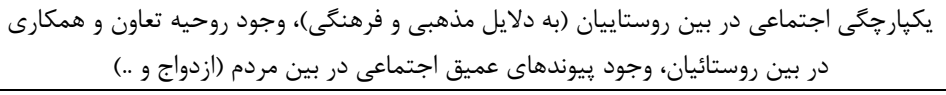 & همبستخى و انسجام & \\
\hline 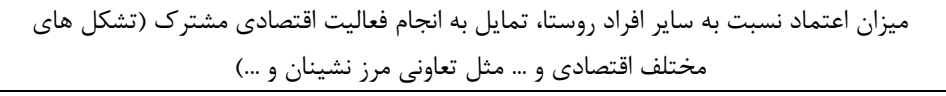 & 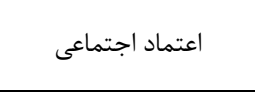 & \\
\hline اجازه اشتغال در بيرون از منزل، امكان ادامه تحصيل در سطوح بالا براى زنان & جايگاه زنان & \\
\hline دسترسى به زيرساخت هاى انرزى (كاز لوله كشى)، دسترسى به سوخت (بنزين، كازوئيل، نفت و ...) & 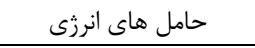 & \multirow{3}{*}{ 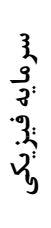 } \\
\hline برخوردارى از ماشين آلات و ادوات كشاورزى شخصى (تراكتور و ...)، دسترسى به ابزار و ماشين آلات & ماشين آلات و ادوات & \\
\hline دسترسى اسان به اينترنت، كيفيت آنتندهى موبايل & بهره مندى از فناورى إزلات و ارتباطات & \\
\hline
\end{tabular}




\begin{tabular}{|c|c|}
\hline 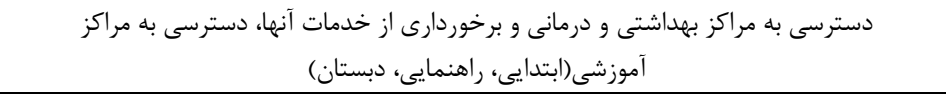 & خدمات آموزشى و بهدى از امكانات و \\
\hline استحكام مسكن، برخودارى از فضاى كافى و مناسب براى نكَهدارى و فراورى محصول، انبار محصول & 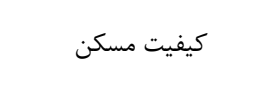 \\
\hline دسترسى راحت به وسايل حملونقل عمومى، دسترسى به راههاى ارتباطى مناسب & حمل و نقل و راه \\
\hline تناسب منابع آبى موجود با نياز كشاورزى & 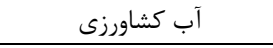 \\
\hline شدت خشكسالى طى سال هاى اخير & كساعدت اقليمى در زمينه \\
\hline دسترسى خانوار به مراتع مرغوب جهت جراى دام & 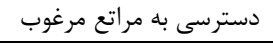 \\
\hline برخوردارى خانوار از زمينهاى مناسب و حاصل خيز براى فعاليتهاى كشاورىى & دسترسى به زمين حاصلخيز \\
\hline 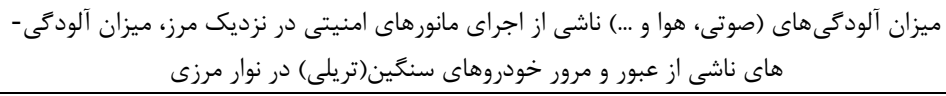 & آلودة \\
\hline
\end{tabular}

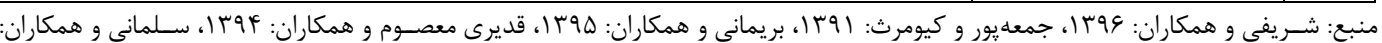

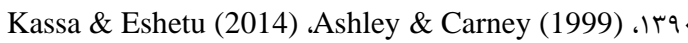

روايى يرسشنامه به وسيله 》تحليل عاملى تأييدى" مورد بررسى قرار كرفت. يافته هاى كيزرماير (Kaiser-Meyer

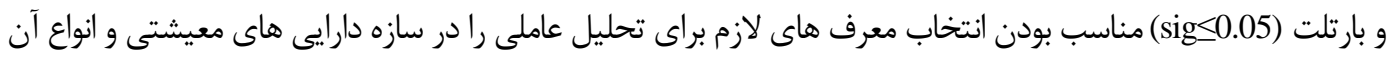

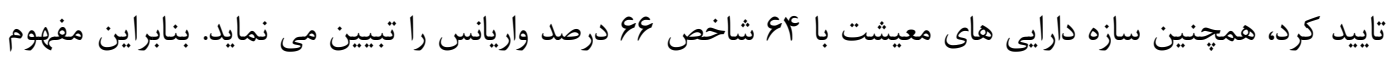

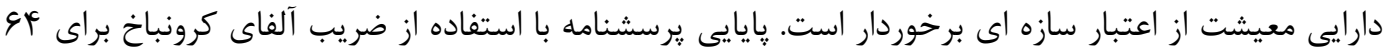

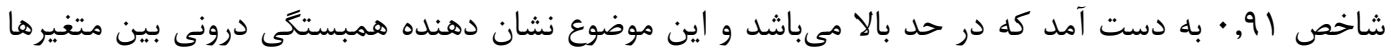

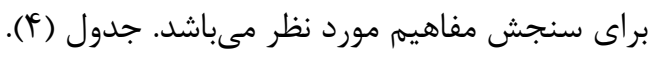

جدول (F). بررسى يايايى و روايى سازه هاى تحقيق

\begin{tabular}{|c|c|c|c|c|c|c|}
\hline \multicolumn{2}{|c|}{$\begin{array}{l}\text { Initial Eigenvalues } \\
\text { Cumulative \%** }\end{array}$} & \multicolumn{2}{|c|}{ آلفاى كرونباخ } & شاخص & بعد & سازه \\
\hline \multirow{5}{*}{$9 \Delta / 9 \Delta$} & $9 / \Delta F$ & \multirow{5}{*}{$\cdot 19 \cdot V$} &.$/ 299$ & If & دارايى انسانى & \multirow{5}{*}{ دارايى معيشت } \\
\hline & $9 \cdot / T V$ & & .1419 & IV & دارايى مالى & \\
\hline & $V K / \Delta q$ & & $\cdot 11 \cdot 1$ & 10 & دارايى اجتماعى & \\
\hline & $49 / 99$ & & $\cdot / N \cdot \Delta$ & IT & دارايى فيزيكى & \\
\hline & $\Delta T / 9 \Lambda$ & & $\cdot 109 \Lambda$ & 4 & دارايى طبيعى & \\
\hline
\end{tabular}

* Extraction Method: Maximum Likelihood.

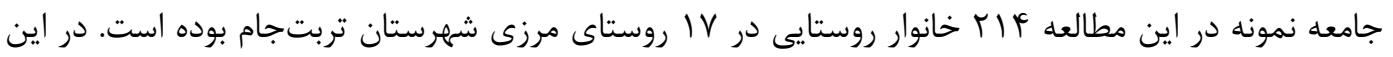

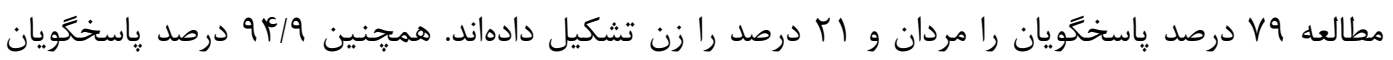

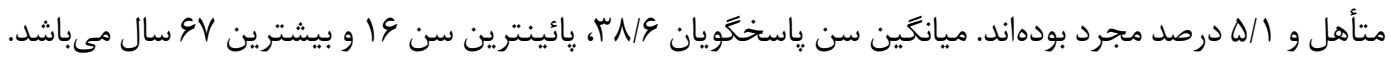

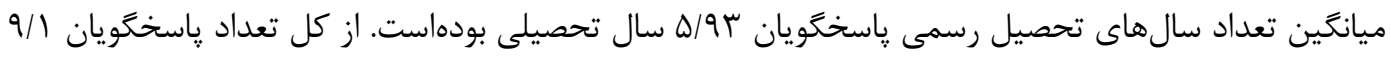

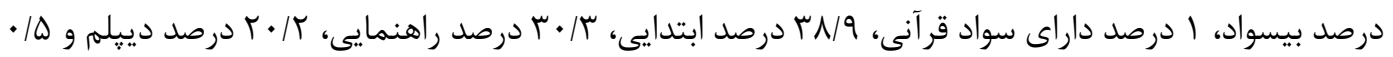


درصد داراى مدرك فوق دييلم بودهاند. بيشتر پاسخكويان (معادل TV/9 درصد) داراى شغل دامدارى بوده اند.

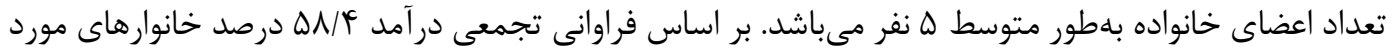

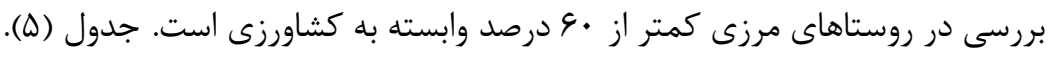

\begin{tabular}{|c|c|c|c|c|c|c|c|}
\hline درصد & فراوانى & مقوله & متغير & درصد & فراوانى & مقوله & متغير \\
\hline $94 / 9$ & $r . r$ & متأهل & \multirow{2}{*}{ وضعيت تاهل } & v9 & 199 & مرد & \multirow[b]{2}{*}{ جنسيت } \\
\hline$\Delta / 1$ & 11 & مجرد & & rI & vq & زن & \\
\hline $9 / 1$ & 19 & بيسواد & \multirow{6}{*}{ تحصيلات } & $1 N / T$ & $r 9$ & بين ·r تا و س سال & \multirow{5}{*}{ سن } \\
\hline 1 & $r$ & قرآنى & & $r f$ & VT & بين •r تا وبr سال & \\
\hline$r N / 9$ & 11 & ابتدايى & & $r F / q$ & vk & بين •f تا وqF سال & \\
\hline$r \cdot / r$ & q4 & راهنمايى & & $9 / 9$ & TI & بين ·ه تا 9ه سال & \\
\hline$r \cdot / r$ & FT & دييله & & $r / \Lambda$ & 9 & بين •و تا و9 سال & \\
\hline$\cdot / 0$ & 1 & فوق دييلم & & & & & \\
\hline
\end{tabular}

يافته هاى استنباطى تحقيق

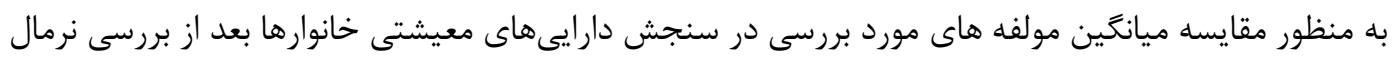

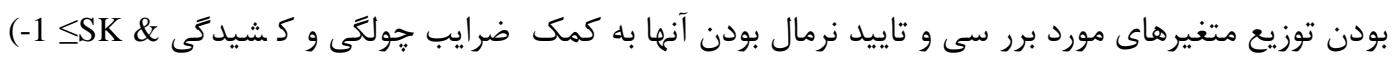

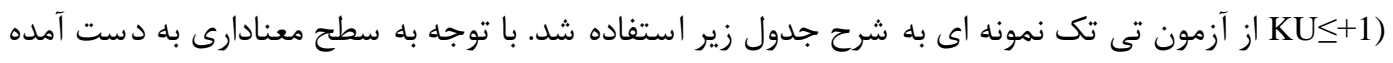

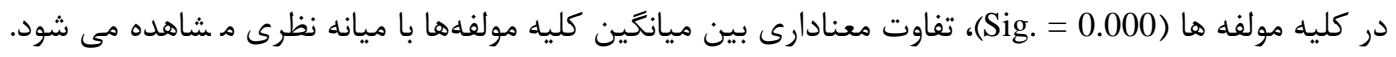

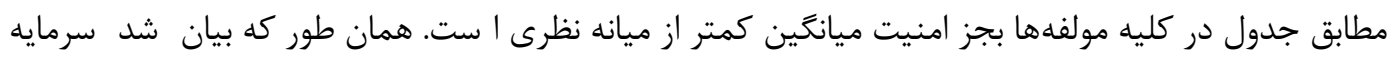

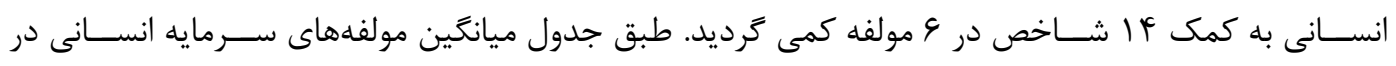

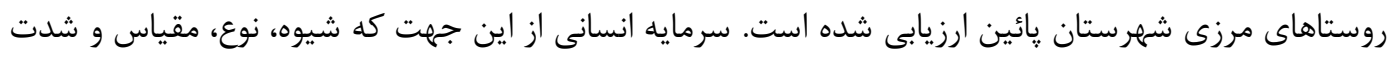

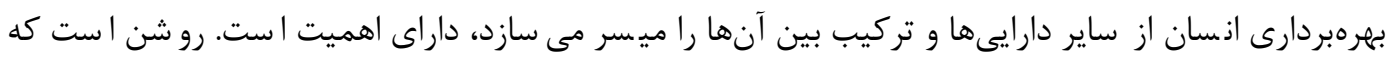

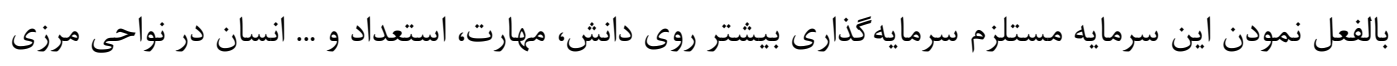

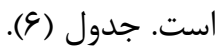

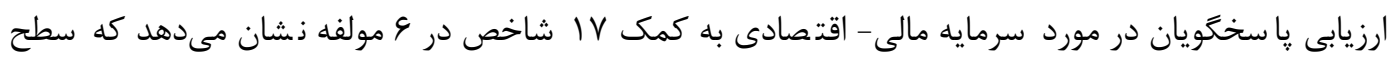

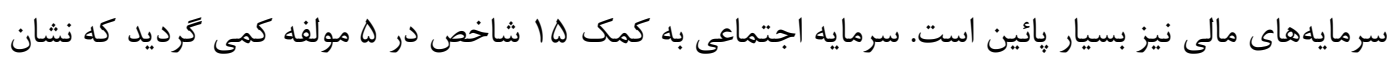

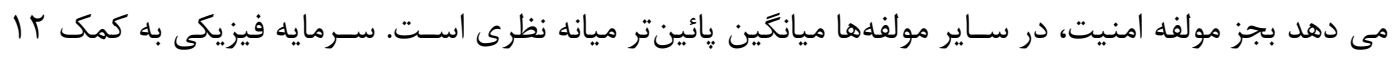

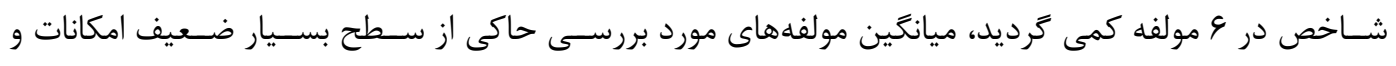

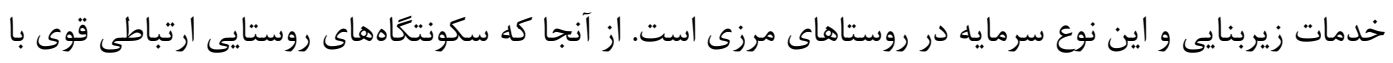

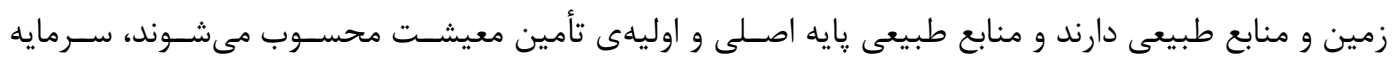

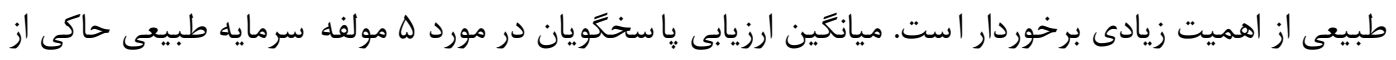

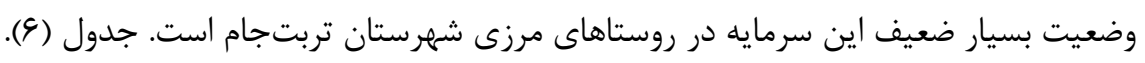


نشريه تحقيقات كاربردى علوم جغرافيايى، سال بيست و يكم، شماره •\&، بهار .+1F

جدول (申). تحليل سرمايه هاى معيشتى در روستاهاى مرزى

\begin{tabular}{|c|c|c|c|c|c|}
\hline \multicolumn{3}{|c|}{ ميانه نظرى=r } & \multirow{2}{*}{ 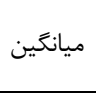 } & \multirow{2}{*}{ مولفه هاى مورد بررسى در سرمايه هاى ه كانه معيشت } & \multirow{2}{*}{ है } \\
\hline اختلاف ميانگين & Sig. & T آماره T & & & \\
\hline$-\cdot / \mu r$ & $\cdot / \cdot$ & $-V / \cdot r$ & $r / 9 \Lambda$ & كميت نيروى كار & \multirow{6}{*}{$\begin{array}{l}G . \\
\xi \\
\xi \\
\xi \\
\xi\end{array}$} \\
\hline$-1 / \cdot V$ & $\cdot / \cdot$ & $-Y Y / \Delta V$ & $1 / 94$ & 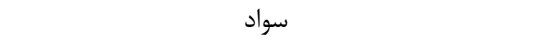 & \\
\hline.$- / 99$ & $\cdot / \cdot$ & $-|V / \Delta|$ & $r / \cdot t^{2}$ & توانايى تنوع بخشى منابع در آمدى & \\
\hline$-\cdot / 1 \Delta$ & $\cdot / \cdot$ & $-1 \% / 9 V$ & $r / l F$ & بهداشت و درمان & \\
\hline.$- / 94$ & $\cdot / \cdot$ & $-19 / V \pi$ & $r / \cdot \Lambda$ & مهارت شغلى و حرفه اي & \\
\hline$-1 / \cdot 0$ & $\cdot / \cdot$ & $-r \cdot \mid q \mu$ & $1 / 9 \Delta$ & كيفيت آب و تغذيه & \\
\hline$-1 / 11$ & $\cdot / \cdot$ & $-4 T / 11$ & $1 / 19$ & كميت در آمد & \multirow{6}{*}{$\begin{array}{l}G \\
\delta \\
: \varepsilon \\
\delta \\
\xi\end{array}$} \\
\hline$-1 / \pi r$ & $\cdot / \cdot$ & $-r \& \mid 8 \Lambda$ & $1 / V V$ & رفاه & \\
\hline$-1 / \cdot 4$ & $\cdot / \cdot$ & $-r Y / 9$. & 1/99 & فعاليت هاى كشاورزى & \\
\hline$-1 / 14$ & $\cdot / \cdot$ & $-r \cdot / V q$ & $1 / 19$ & 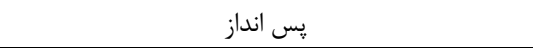 & \\
\hline$-1 / \pi r$ & $\cdot / \cdot$ & $-r N / G F$ & $1 / 9 \Lambda$ & اعتبارات و بيمه & \\
\hline.$- / 9 V$ & $\cdot / \cdot$ & $-10 / r \varphi$ & $t / r$ & كيفيت درآمد & \\
\hline$-\cdot / \mathrm{V} 9$ & $\cdot / \cdot$ & $-1 \cdot / f F$ & $T / T)$ & مشاركت & \multirow{5}{*}{$\begin{array}{l}q_{n} \\
\xi \\
\xi \\
\xi \\
\xi \\
\xi\end{array}$} \\
\hline$\cdot / V r$ & $\cdot / \cdot$ & $19 / T F$ & $r / V \mu$ & امنيت & \\
\hline$-\cdot / \pi \Delta$ & $\cdot / \cdot$ & $-r / q V$ & T/צD & همبستىى و انسجام اجتماعى & \\
\hline$-1 / \pi$ & $\cdot / \cdot$ & $-Y Y / A V$ & $1 / v$ & اعتماد اجتماعى & \\
\hline$-\cdot / \Lambda$ & $\cdot / \cdot$ & $-11 / 91$ & $r / T \cdot$ & جايگاه زنان & \\
\hline$-1 / \pi 1$ & $\cdot / \cdot$ & $-r N / / \Lambda$ & 1/VG & دسترسى به حامل هاى انررى & \multirow{6}{*}{ 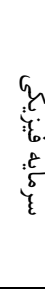 } \\
\hline$-1 / 11$ &.$/ \cdot$ & $-r|/| q \mid$ & $1 / A T$ & ماشين آلات و ادوات كشاورزى & \\
\hline$-1 / T V$ & $\cdot / \cdot$ & $-\mu 1 / V 9$ & $1 / 94$ & بهره مندى از فناورى اطلاعات و ارتباطات & \\
\hline$-1 / \cdot \Delta$ & $\cdot / \cdot$ & $-19 / 91$ & 1/90 & بهره مندى از امكانات و خدمات آموزشى و بهداشتى & \\
\hline$-\cdot / 9$ & $\cdot / \cdot$ & $-\mid F / \Delta F$ & $4 / 1 \cdot$ & كيفيت مسكن & \\
\hline$-1 / \pi \Delta$ & $\cdot / \cdot$ & $-\mu) / \Lambda \cdot$ & $1 / 90$ & امكانات حمل و نقل و راه & \\
\hline$-1 / 14$ & $\cdot / \cdot$ & $-r I / r T$ & $1 / 19$ & آلودگى هاى محيطى & \multirow{5}{*}{$\begin{array}{l}\{ \\
\vdots \\
\xi \\
: \varepsilon \\
\delta \\
\xi\end{array}$} \\
\hline$-1 / \pi F$ & $\cdot / \cdot$ & $-4 Y / 19$ & $1 / 99$ & تناسب منابع آبى موجود با نياز كشاورزى & \\
\hline$-\cdot|\Delta|$ & $\cdot / \cdot$ & $-r / 9 \Delta$ & $r / 4 q$ & مساعدت افليمى در زمينه كشاورزى و دامدارى & \\
\hline$-1 / 14$ & $\cdot / \cdot$ & $-19 / \pi \Delta$ & $1 / 1 \Lambda$ & دسترسى به مراتع مرغوب & \\
\hline$-1 / \cdot r$ & $\cdot / \cdot$ & $-14 / 91$ & $1 / 91$ & برخوردارى از زمين هاى مناسب و حاصلخيز & \\
\hline
\end{tabular}

در ادامه به منظور مقايسه ميانكَين ه سرمايه/دارايى معيشتى خانوارهاى ساكن در روستاهاى مرزى بعد از بررسى نرمالبودن توزيع متغيرهاى مورد بررسى و تاييد نرمالبودن آنها به كمك ضرايب جولنى و كشيدگى إنى

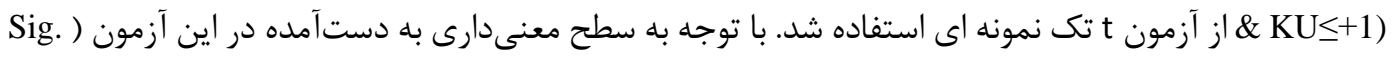

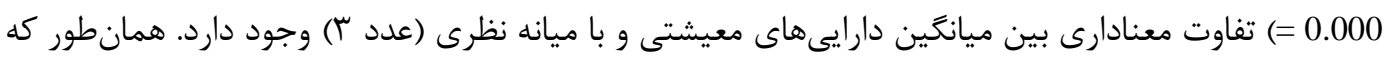

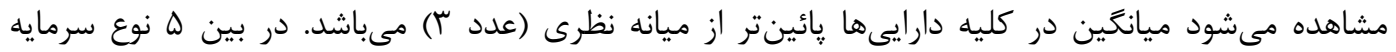

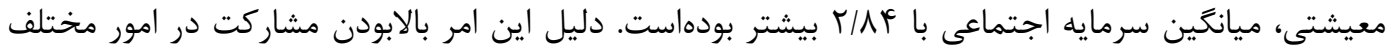

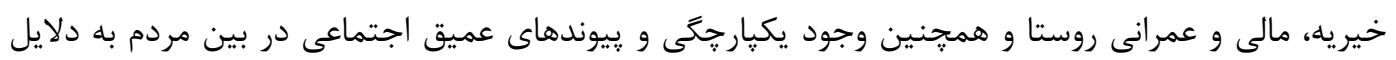


مذهبى است. لازم به ذكر است كه بيش از هو درصد ساكنان روستاهاى مرزى شهرستان تربت جام اهل تسنن

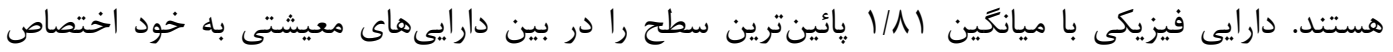

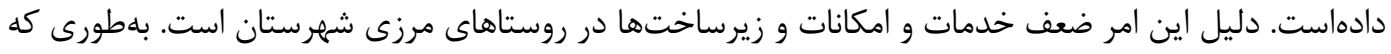

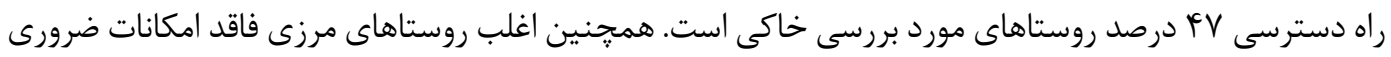

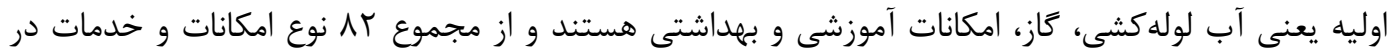

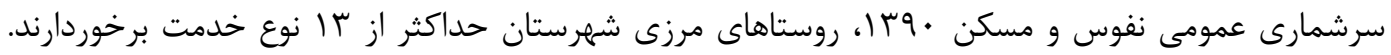

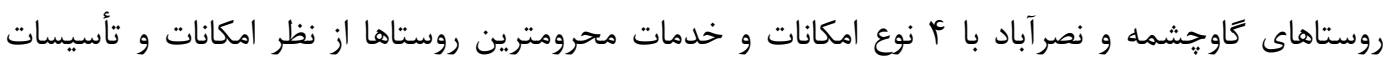

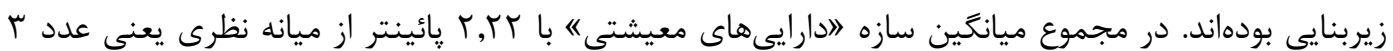

$$
\text { بوده و در طيف ليكرت در حد "كمه سنجش شدهاست. جدول (V). }
$$

جدول (V). نتايج آزمون تى تك نمونه به منظور ارزيابى پاسخ خانوارهاى مورد بر رسى دارايى معيشتى

\begin{tabular}{|c|c|c|c|c|c|c|c|}
\hline \multicolumn{6}{|c|}{ Test Value $=3$} & \multirow{3}{*}{ ميانكين } & \multirow{3}{*}{ نواع سرمايههاى معيشتى } \\
\hline \multicolumn{2}{|c|}{$\begin{array}{c}\text { 95\% Confidence Interval of the } \\
\text { Difference }\end{array}$} & \multirow{2}{*}{$\begin{array}{c}\text { Mean } \\
\text { Difference }\end{array}$} & \multirow{2}{*}{$\begin{array}{l}\text { Sig. (2- } \\
\text { tailed) }\end{array}$} & \multirow[t]{2}{*}{$\mathrm{df}$} & \multirow[t]{2}{*}{$\mathrm{t}$} & & \\
\hline Upper & Lower & & & & & & \\
\hline.$- / 1 \mathrm{q}$ &.$- / 94$ & $-\cdot 119$ & . & rIr & $-Y F|\varepsilon|$ & $4 / T$ & سرمايه انسانى \\
\hline$-1 / \cdot 0$ & $-1 / 11$ & $-1 / 1 T$ & $\cdot$ & TIT & $-r T / \mu V$ & I/AV & سرمايه مالى \\
\hline-.1 .4 & $-\cdot \pi r$ & -.110 & $.1 \cdot .1$ & rir & $-r / 4 q$ & r/AF & سرمايه اجتماعى \\
\hline$-1 / 14$ & $-1 / T 4$ & $-1 / 11$ & . & rir & $-r / N \mid \Lambda I$ & $1 / 11$ & سرمايه فيزيكى \\
\hline.$- / 1 \mathrm{q}$ & -.199 & $-\cdot / 1 \Lambda$ & . & $r .$. & $-r \cdot 19$ & T/TT & سرمايه طبيعى \\
\hline$-\cdot / V T$ & $-\cdot / \mathrm{AT}$ & $-\cdot / V V$ & . & rIT & $-r \cdot / \& \Delta$ & T/TT & دارايىهاى معيشت \\
\hline
\end{tabular}

در ادامه به كمك آزمون فريدمن' به مقايسه دارايىهاى معيشتى از نظر ميانكين رتبهها نسبت به هم يرداخته

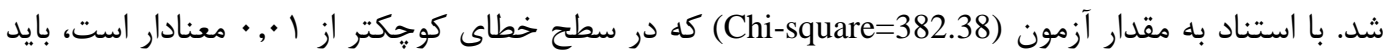

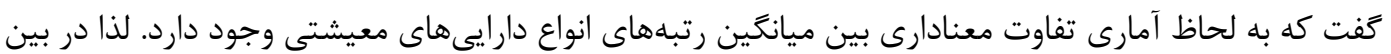

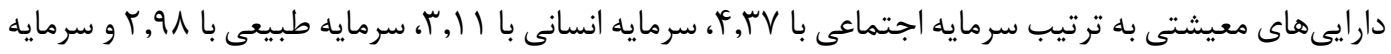

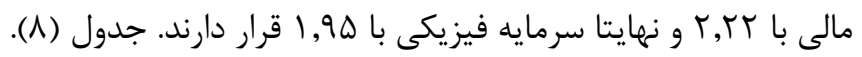

جدول (^). آزمون فريدمن به منظور رتبهبندى انواع دارايى هاى معيشتى خانوارهاى ساكن در روستاهاى مرزى

\begin{tabular}{|c|c|}
\hline ميانكين رتبه ها & دارايى هاى معيشتى \\
\hline$r / 11$ & سرمايه انسانى \\
\hline$T / T T$ & سرمايه مالى \\
\hline F/VT & سرمايه اجتماعى \\
\hline $1 / 90$ & سرمايه فيزيكى \\
\hline$r / 91$ & سرمايه طبيعى \\
\hline 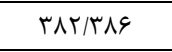 & Chi-Square \\
\hline$\cdot, \cdots$ & Asymp. Sig. \\
\hline
\end{tabular}

1. Friedman Test 
تحليل فضايى دارايىهاى معيشتى در روستاهاى مرزى

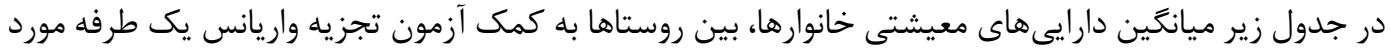

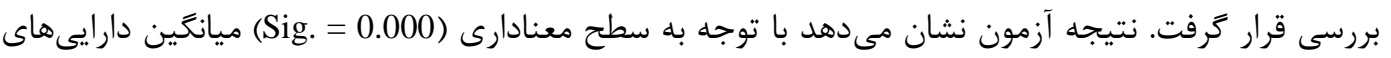

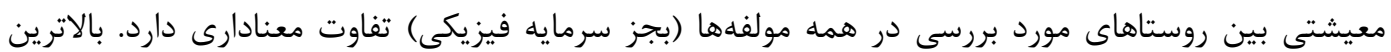

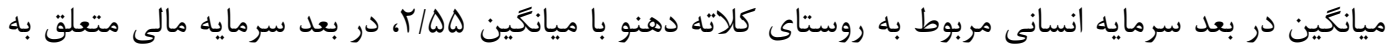

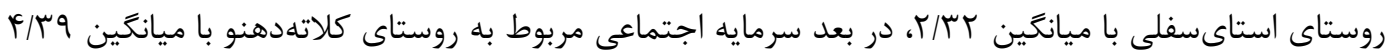

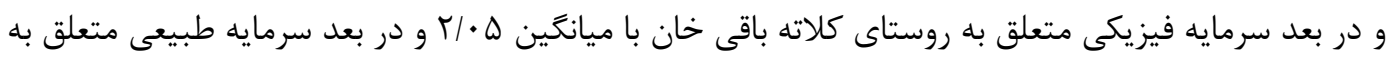

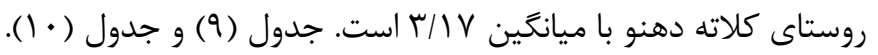

جدول (9). آزمون تحليل واريانس يك طرفه براى مقايسه ميانگين دارايى هاى معيشتى بين روستاهاى مورد بررسى

\begin{tabular}{|c|c|c|c|c|c|c|}
\hline دارايى هاى & سرمايه طبيعى & سرمايه فيزيكى & سرمايه اجتماعى & سرمايه مالى & سرمايه انسانى & Anova \\
\hline$r / 199$ & $\Delta / \Lambda \Delta F$ & $1 / .9 \mathrm{~V}$ & $9 / V 9 \vee$ & r/A\&A & T/QGY & F آماره F \\
\hline $.1 \%$ &.$\%$ & . &.$/$. & $.1 \%$ &.$/$. & سطح معنادارى \\
\hline
\end{tabular}

جدول (•(1). ميانگين دارايى هاى معيشتى به تفكيك روستاهاى مورد بررسى

\begin{tabular}{|c|c|c|c|c|c|c|}
\hline دارايى هاى & سرمايه طبيعى & سرمايه فيزيكى & سرمايه اجتماعى & سرمايه مالى & سرمايه & 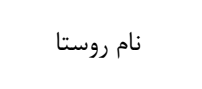 \\
\hline$r / \cdot 9$ & $1 / \Delta 9$ & $1 / \Delta \Delta$ & $r / 9 V$ & $1 / 91$ & $r / \Lambda r$ & كلاته حميد \\
\hline$r / 1$. & $r / \Gamma$. & $1 / v 9$ & r/G & I/VQ & $r / \cdot 1$ & ابراهيم باى \\
\hline$r / r q$ & 1/9r & $1 / 90$ & $r / V V$ & $1 / 11$ & $r / r \Lambda$ & سياه خوله \\
\hline T/TY & $1 / \wedge \Delta$ & $1 / 09$ & T/AV & $r / \cdot r$ & $r / / \Lambda$ & كنده سوخته \\
\hline$r / T \Delta$ & T/QT & $1 / V 1$ & r/AD & $r / \cdot V$ & $r / r q$ & كرماسى \\
\hline T/KT & T/QT & $r / \cdot \Delta$ & r/TA & $r / \cdot 1$ & $r / \cdot \Lambda$ & كلاته باقى خان \\
\hline$T / T V$ & T/TF & $1 / V \Delta$ & $r / .9$ & $r / 1$ & $1 / 94$ & نصر آباد \\
\hline$r / I V$ & $1 / V V$ & $1 / 1 \Delta$ & $r / \& V$ & $1 / 91$ & $r / .9$ & ملوى عليا \\
\hline $1 / 9$. & $1 / \wedge \Delta$ & $1 / 9$. & T/Tr & $1 / 41$ & $1 / V$. & كاريزى حاجى يسند \\
\hline r/9 & r/IV & 1/19 & $r / \pi q$ & $1 / N r$ & $r / \Delta \Delta$ & كلاته دهنو \\
\hline$r / l$. & $r / r$ & $1 / 9 V$ & T/AT & $1 / \Delta 9$ & $r / / \Delta$ & سنَ آب \\
\hline$r / \tau$. & $4 / 11$ & $1 / V \Delta$ & $r / I V$ & $1 / \Delta 9$ & $r / \Delta V$ & سقر خشمه سفلى \\
\hline$T / T)$ & I/Ar & I/AF & T/G & $1 / 91$ & $r / \cdot T$ & كلاته صمدخان \\
\hline$r / \pi)$ & $r / T \Lambda$ & $1 / 91$ & $r / \Lambda r$ & $r / \cdot \Delta$ & T/Kr & يده موسى خان \\
\hline$r / 4)$ & $r / 4$. & $1 / A r$ & $r / \cdot \varphi$ & T/T & $r / M F$ & استاى سفلى \\
\hline 1/94 & $1 / v$ & $1 / 9$. & $r / T V$ & $1 / \Delta \Lambda$ & $1 / N \Delta$ & كاوجشمه \\
\hline$T / T^{f}$ & $r / .9$ & 1/19 & $r / V \Delta$ & $1 / 11$ & $1 / 9 V$ & جشمه انجير \\
\hline
\end{tabular}




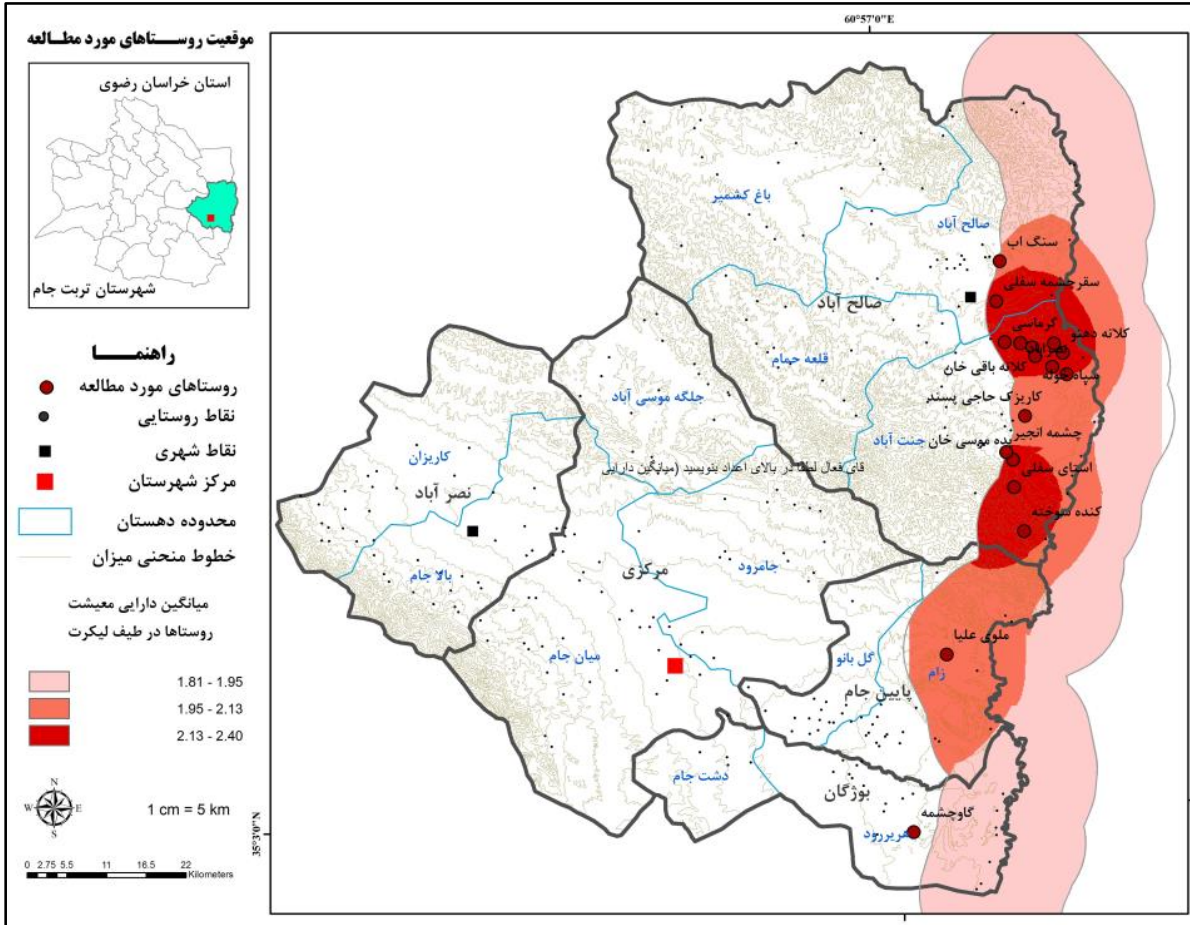

شكل (ه): نمايش فضايى دارايى هاى معيشتى خانوارهاى روستايى ساكن در نواحى مرزى شهرستان تربت جام

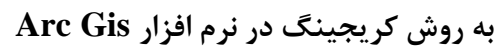

بررسى رابطه بين متغيرهاى فردى خانوارهاى ساكن در نواحى مرزى با دارايىهاى معيشتى

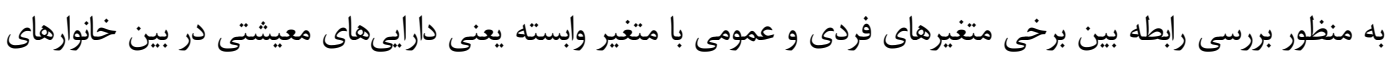

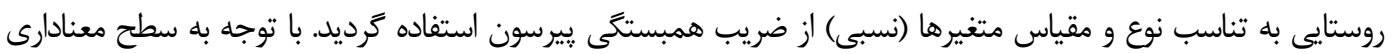
(Sig. $\geq 0.05$ )، بين متغيرهاى سن، تعداد سالماى تحصيل و دارايىهاى معيشتى رابطه معنادارى وجود ندارد. اما بين تعداد افراد خانوار نيز با توجه به سطح معنى دارى (1 •/•) و دارايىهاى معيشتى رابطه مستقيم معنادارى با شدت IV IV • وجود دارد.

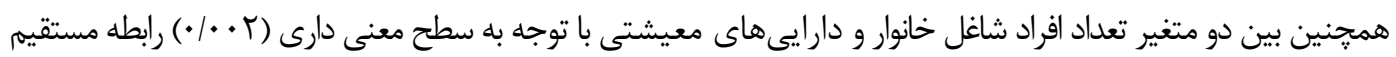

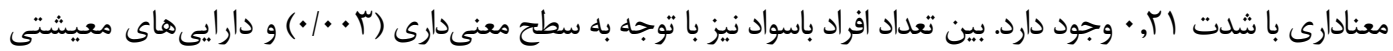
رابطه مستقيم معنادارى با شدت ז, • وجود دارد. جدول (1).

\begin{tabular}{|c|c|c|c|}
\hline سطح معنادارى & ضريب همبستى & متغير دوم & متغير اول \\
\hline$\cdot \pi v$ & .1 .9 & دارايىهاى معيشتى & سن \\
\hline.$/ 1 \mathrm{~F}$ & $-\cdot 11$ & دارايىهاى معيشتى & تعداد سالهاى تحصيل \\
\hline $.1 \cdot 1$ &.$/ 1 V$ & دارايىهاى معيشتى & تعداد افراد خانوار \\
\hline$\%$. & $\cdot / \pi 1$ & دارايىهاى معيشتى & تعداد شاغل خانوار \\
\hline$\cdot \cdot \cdot r$ & $\cdot \pi$ & دارايىهاى معيشتى & تعداد افراد باسواد \\
\hline
\end{tabular}


همجنين براى روشنتر شدن رابطه بين متغيرهاى جنسيت و وضعيت تأهل با دارايىهاى معيشتى از آزمون T دو نمونه مستقل

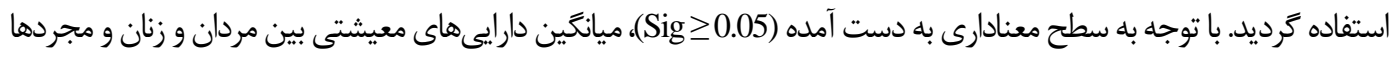

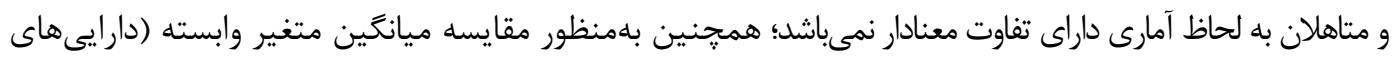

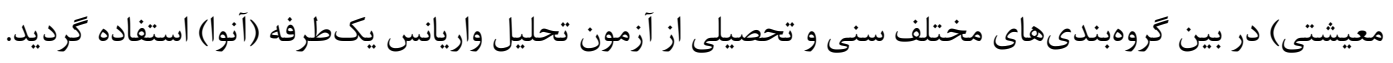

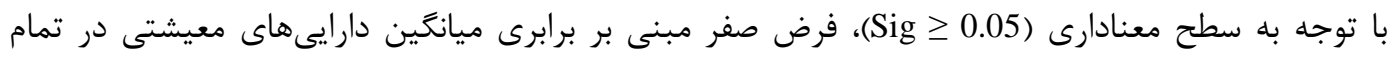

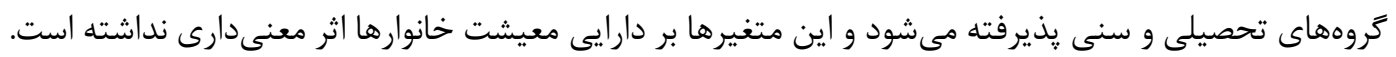

\section{بررسى رابطه بين انواع دارايى هاى معيشتى}

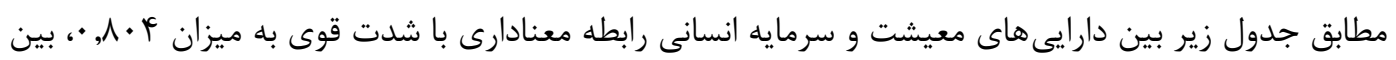

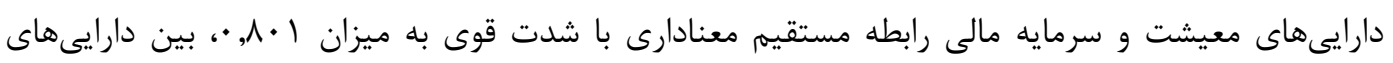

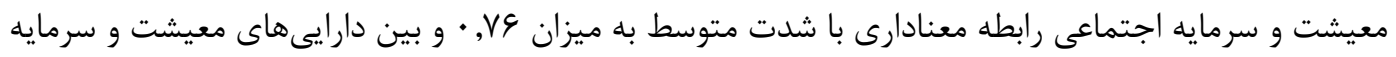

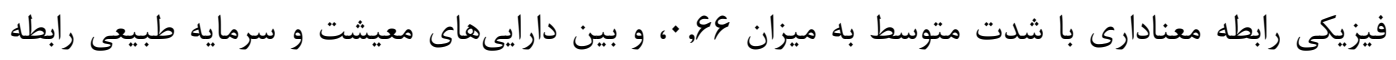

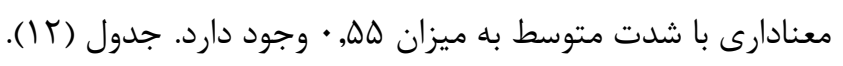

\begin{tabular}{|c|c|c|c|c|c|c|}
\hline دارايى هاى & | سرمايه طبيعى & سرمايه فيزيكى & سرمايه اجتماعى & سرمايه مالى & & \\
\hline$\cdot \mid \Lambda \cdot F$ & • rur & $\cdot / r \Lambda \Lambda$ & • IDKT & $\cdot \mid \Delta \Delta \Delta$ & ضر يب همبستكى پيرسون & \multirow{3}{*}{ سرمايه انسانى } \\
\hline$\cdot$ & $\cdot$ & $\cdot$ & $\cdot$ & · & سطح معنادارى & \\
\hline rIf & $r \cdot 1$ & TIF & TIF & TIF & تعداد & \\
\hline$\cdot 11 \cdot 1$ & $\cdot / T V V$ &.$/ 4 q$. & $\cdot / r q$. & & ضر يب همبستكى بيرسون & \multirow{3}{*}{ سرمايه مالى } \\
\hline · & $\cdot$ & $\cdot$ & · & & سطح معنادارى & \\
\hline rIf & $r \cdot 1$ & TIF & TIF & & 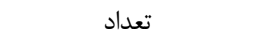 & \\
\hline ./VG. & . IDTF & $\cdot / \pi \cdot 1$ & & & ضر يب همبستگى ييرسون & \multirow{3}{*}{ سرمايه اجتماعى } \\
\hline$\cdot$ & $\cdot$ & $\cdot$ & & & سطح معنادارى & \\
\hline rIf & $r \cdot 1$ & rif & & & تعداد & \\
\hline . 1994 & - If4s & & & & ضريب همبستگى پيرسون & \multirow{3}{*}{ سرمايه فيزيكى } \\
\hline$\cdot$ & . & & & & سطح معنادارى & \\
\hline rIf & $r \cdot 1$ & & & & تعداد & \\
\hline TH & & & & & ضر يب همبستگى ييرسون & \multirow{3}{*}{ سرمايه طبيعى } \\
\hline$\cdot$ & & & & & سطح معنادارى & \\
\hline$r \cdot 1$ & & & & & تعداد & \\
\hline
\end{tabular}

**. Correlation is significant at the 0.01 level (2-tailed).

سكونتخاههاى مرزى همزمان از بار فشار دوكانهى توسعهنيافتكى و حاشيداى بودن در محدوديت قرار دارند؛

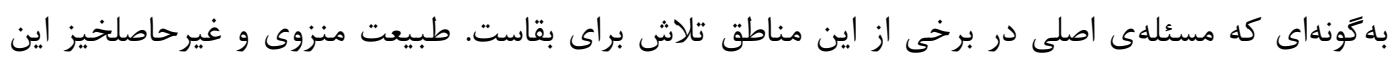

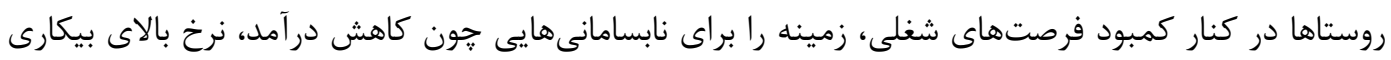


بلهويزه براى جوانان و فقر بالاى اقتصادى و نهايتا مهاجرتهاى گسترده روستا-شهرى و تخليه روستاهاى مرزى

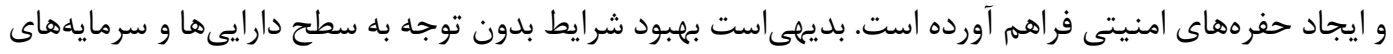

معيشتى خانوارها ممكن نيست.

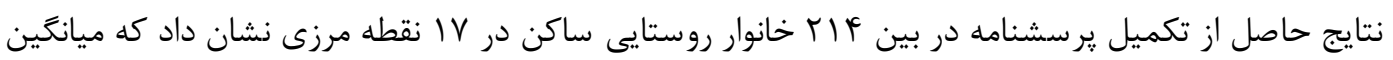

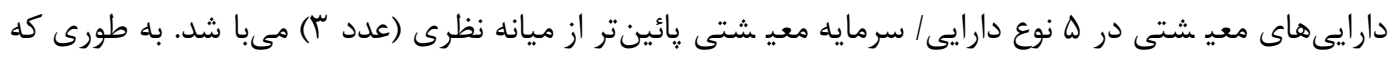

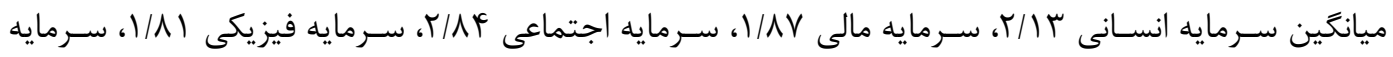

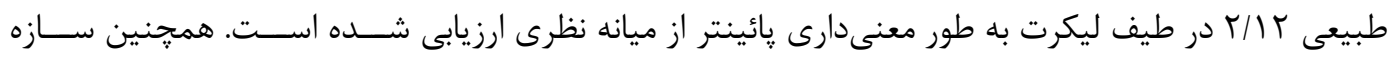

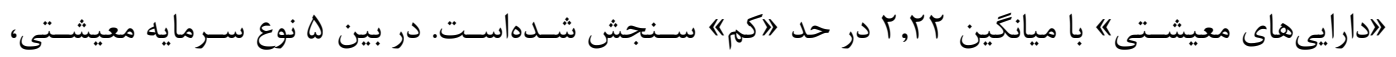

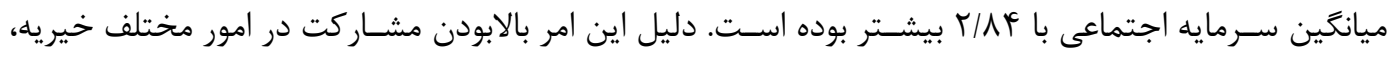

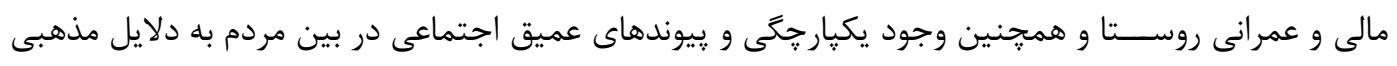

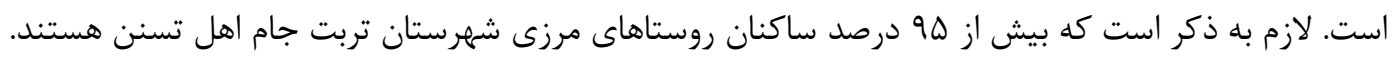

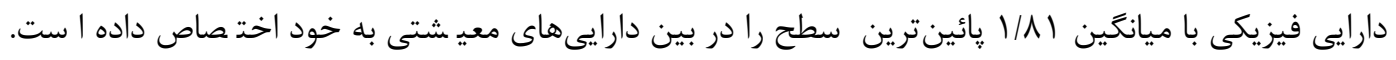

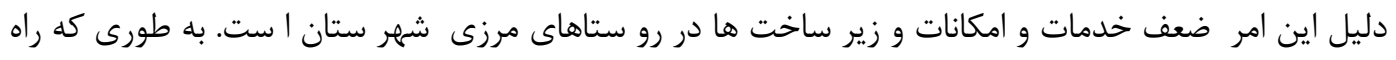

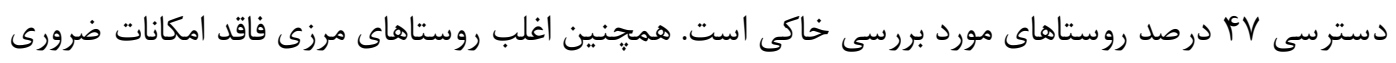

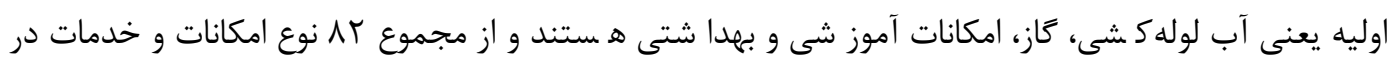

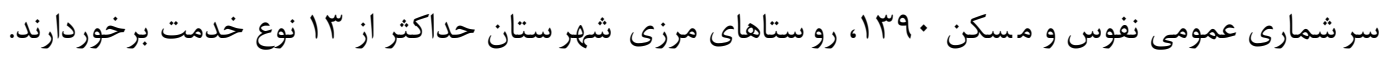

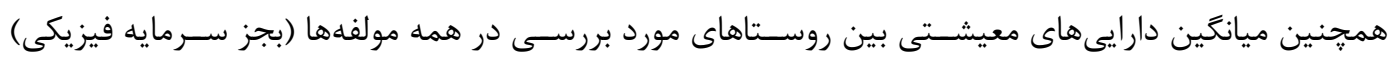

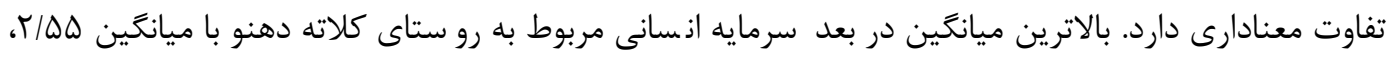

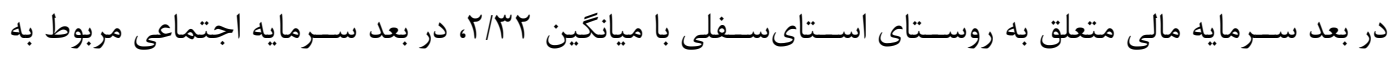

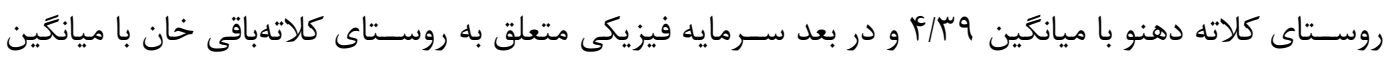

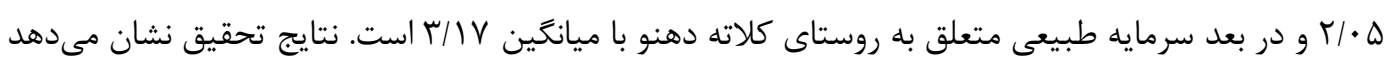

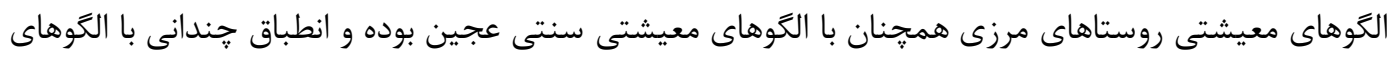

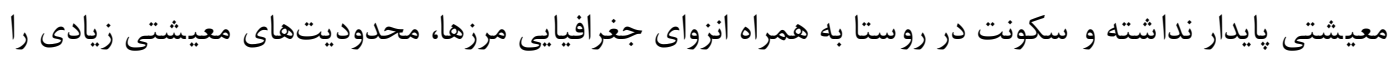
براى خانوارهاى ساكن ايجاد نموده است. نئن

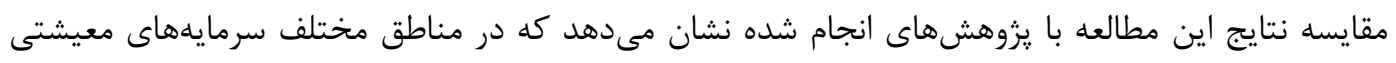

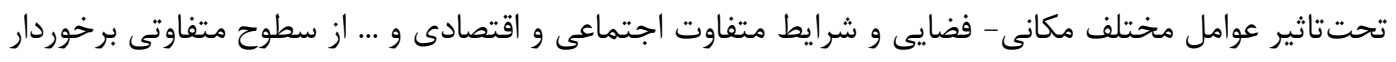

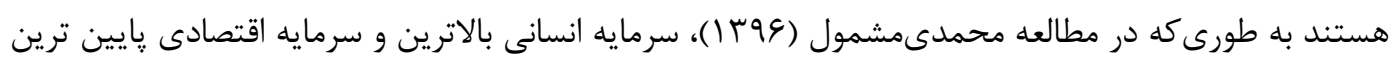

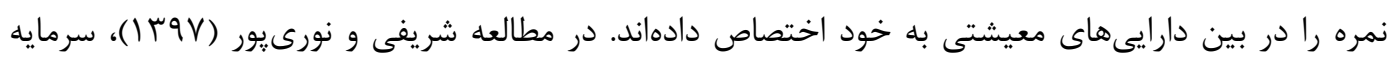

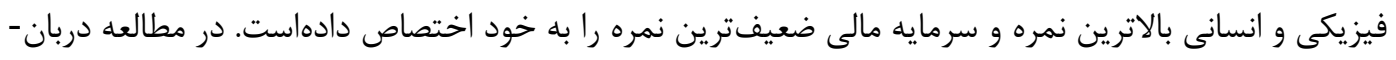

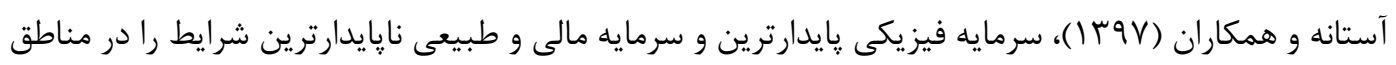

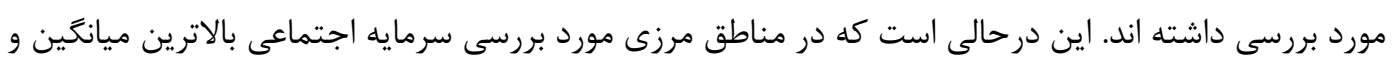

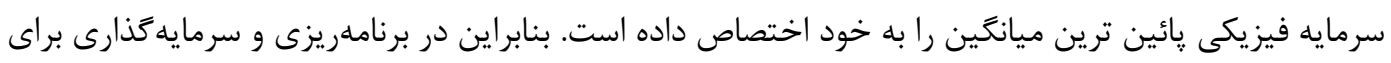




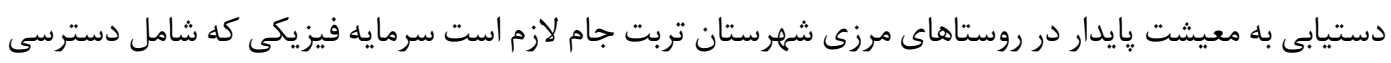

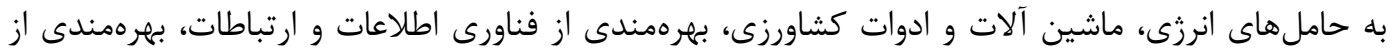

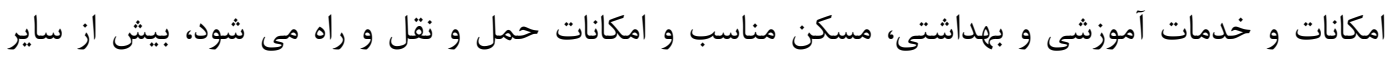
سرمايهها مورد توجه قرار خيرند.

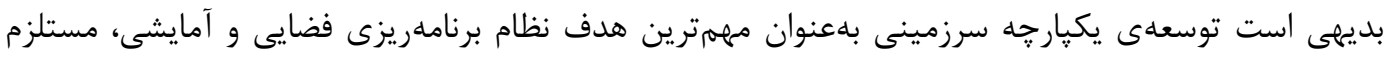
بيشرفت همسان و درخور همهى مناطق جغرافيايى است، زيرا مناطق مرزى هر كشور به سبب موني موقعيت خاص

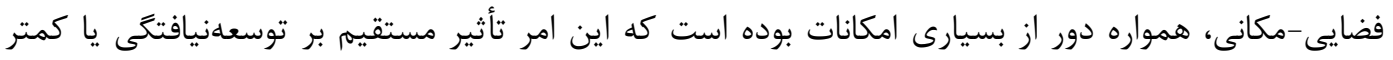

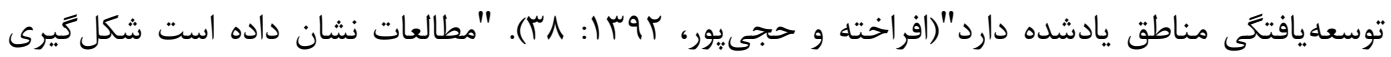
قطبهاى توسعه در مركز و غرب كشور نبايد توجه دولتمردان و برنامهريزان رادر سطح ملى و منطقهاى از نواحى إنى

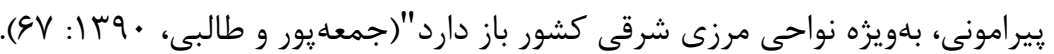

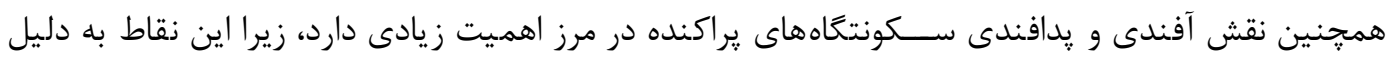

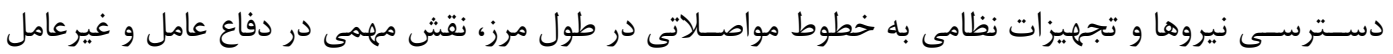

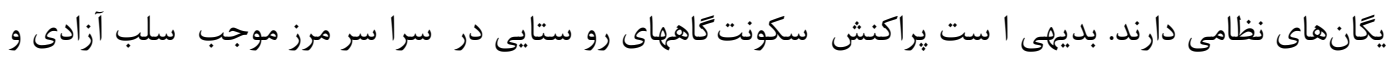

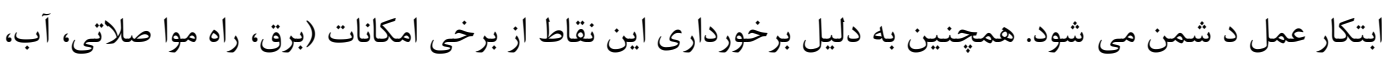

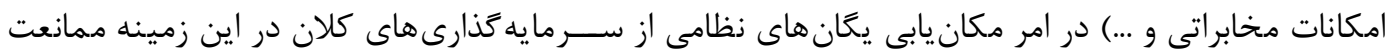

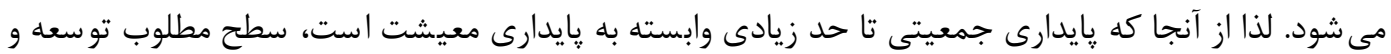

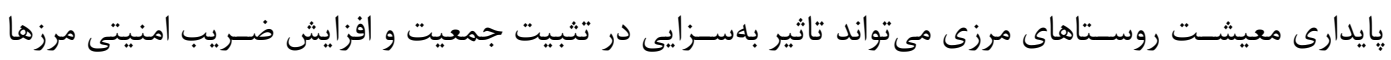

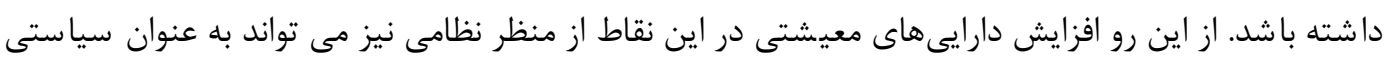
دفاعى و مطلوب مورد توجه قرار كيرد.

منابع

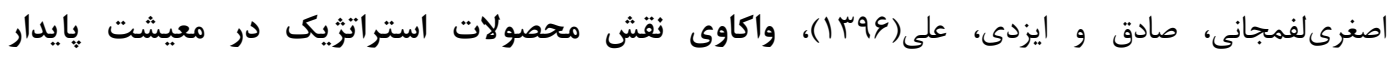

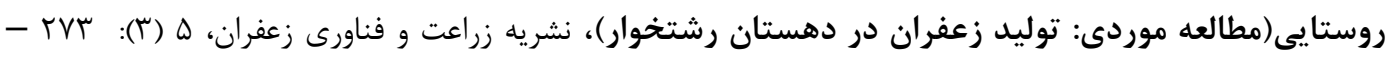
ז

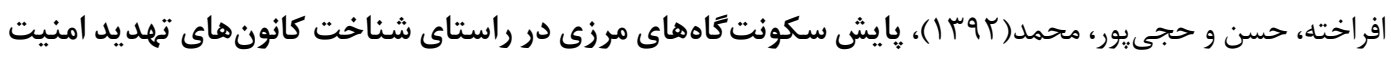

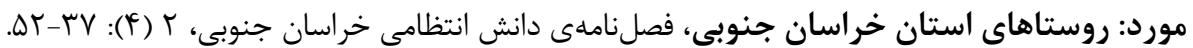

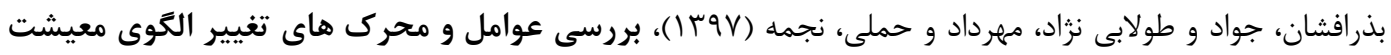

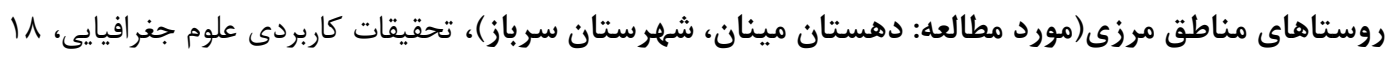

ID.-1YV، (Yq)

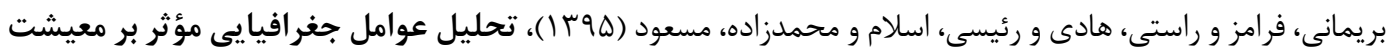

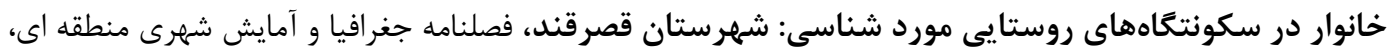
$1 \Delta-99 ،(1 \wedge) 9$

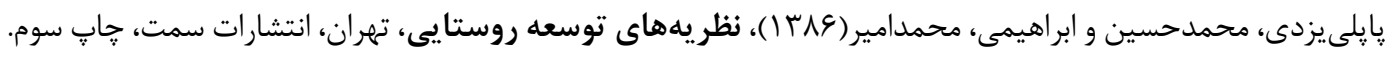


توكلى، مرتضى و احمدى، شيركو و فاضلنيا، غريب(9ه (1)، تحليل عوامل مؤثر بر معيشت روستايى (بررسى موردى:

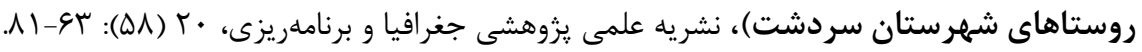

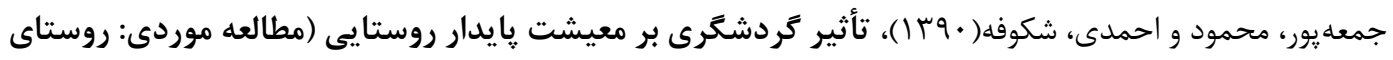

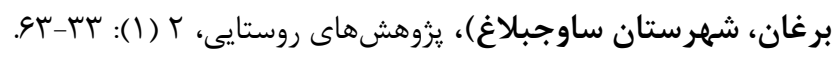

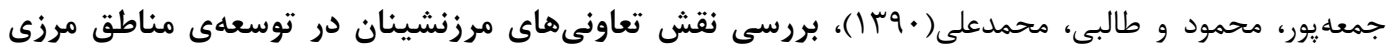

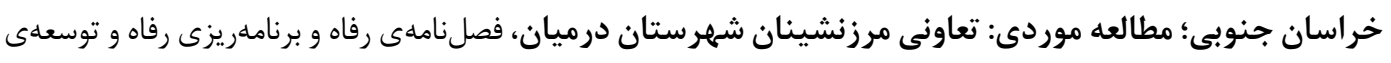

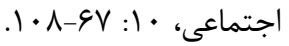

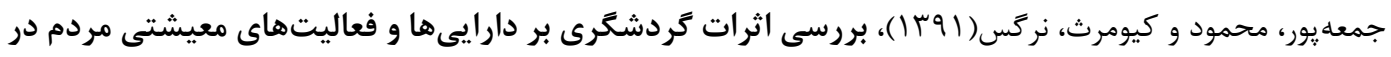

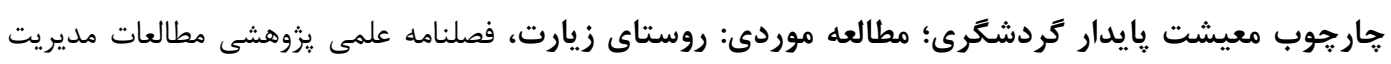
كردشكرى، V V V

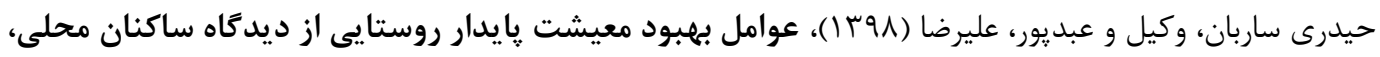

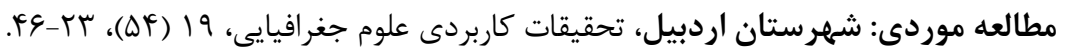

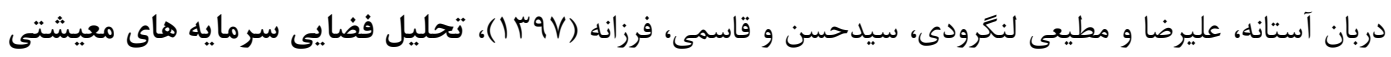

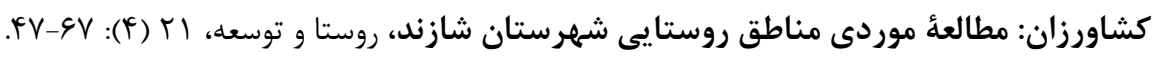

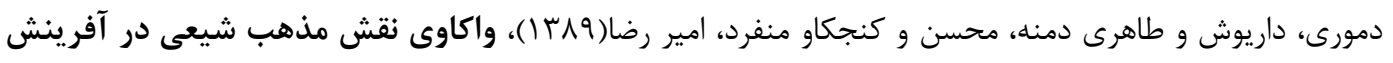

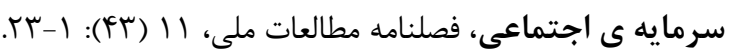

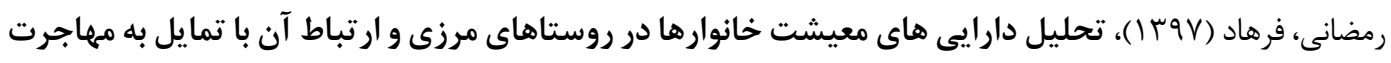

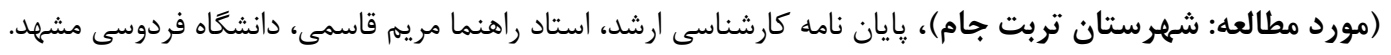

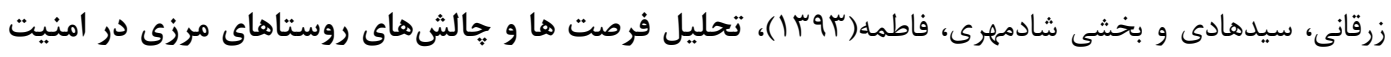

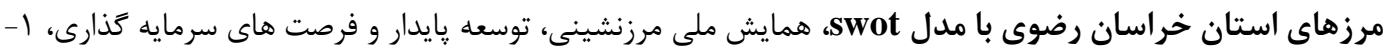

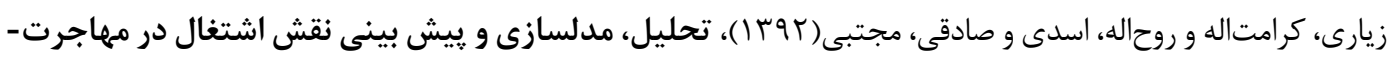

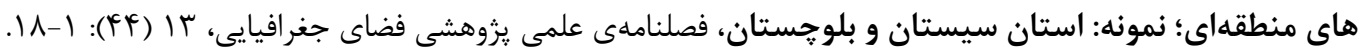

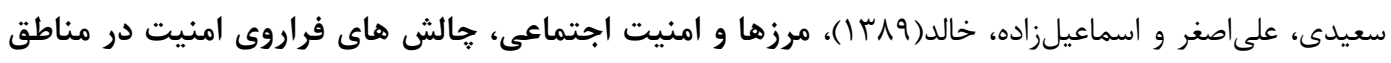

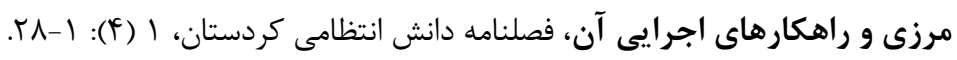

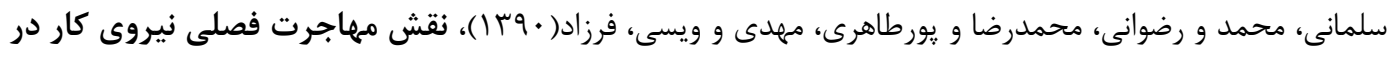

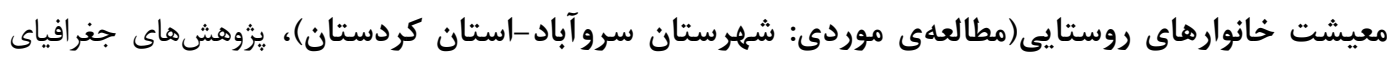

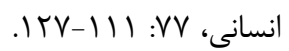

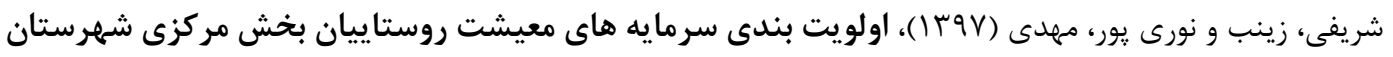

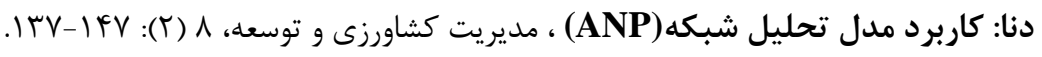

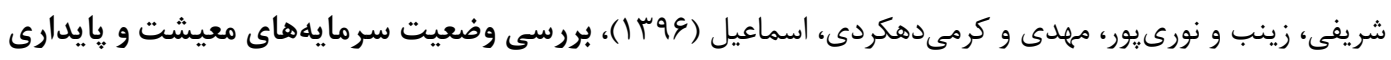

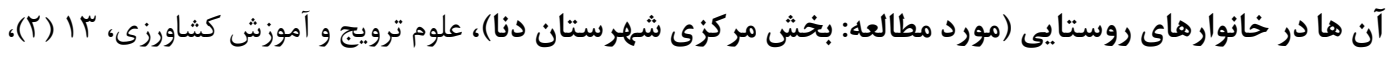


نشريه تحقيقات كاربردى علوم جغرافيايى، سال بيست و يكم، شماره •\&، بهار ••|F

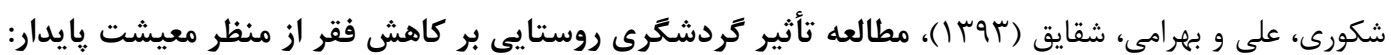

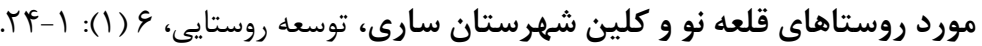

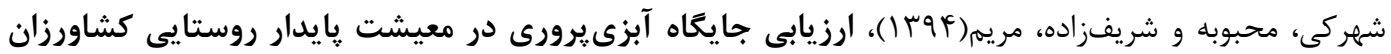

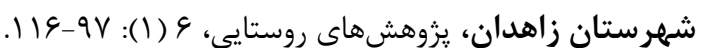

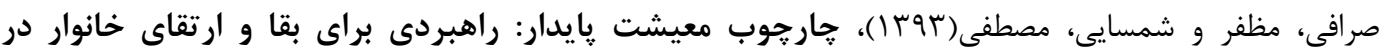

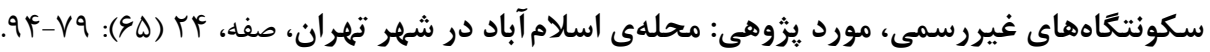

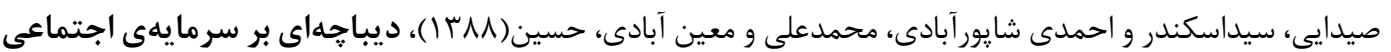

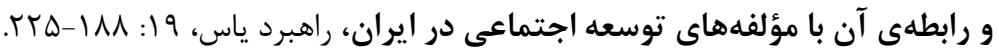

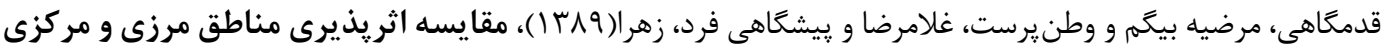

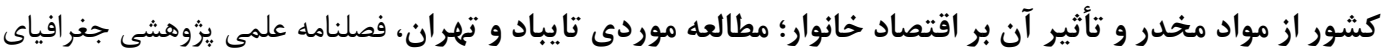

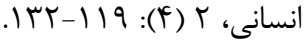

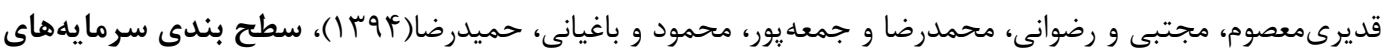

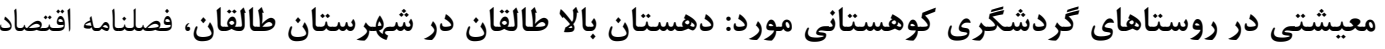

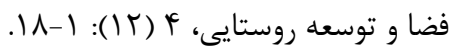

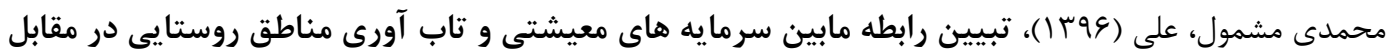

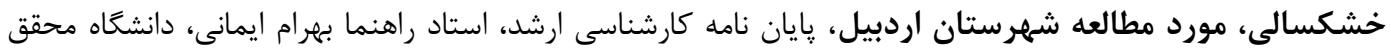
اردبيلى آلى

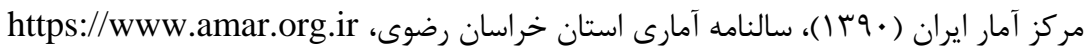

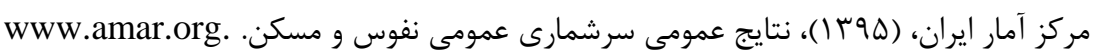

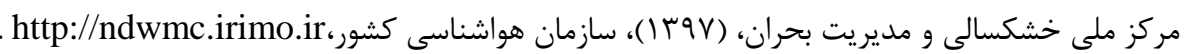

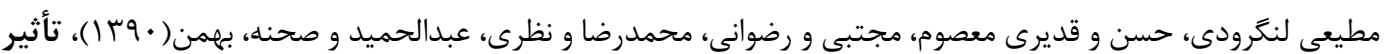

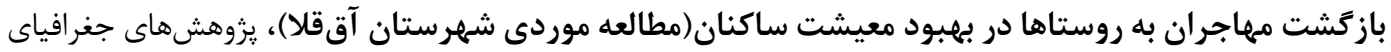
انسانى، VY

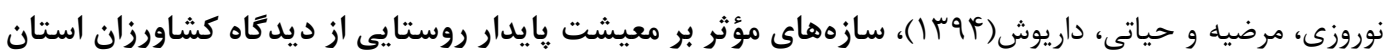

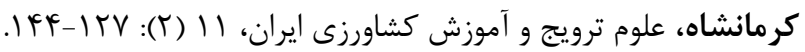

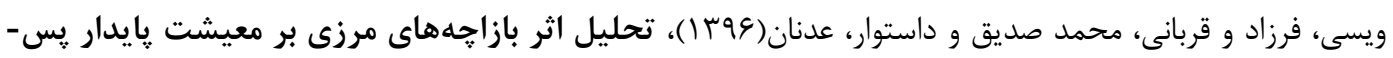

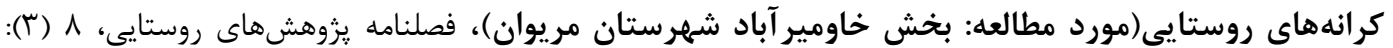

Ashley, C., \& Carney, D. (1999). Sustainable livelihoods: Lessons from early experience (Vol. 7, No. 1). London: Department for International Development. Bebington, A. (1999). Capitals and capabilities: a framework for analyzing peasant viability, rural livelihoods and poverty. World development, 27(12), 2021-2044.

Chambers, Robert and R. Conway, Gordon (1991), Sustainable rural livelihoods: practical concepts for the 21 st century, IDS Discussion Paper 296, PP 1-27. 
Chen, H., Shivakoti, G., Zhu, T., \& Maddox, D. (2012). Livelihood sustainability and community based co-management of forest resources in China: changes and improvement. Environmental management, 49(1), 219-228.

CHF, (2005), Sustainable Livelihoods Approach Guidelines, Partners in Rural Development, Chapel, Ottawa, Canada.

De Haas, H. (2009). Remittances and social development. In Financing Social Policy (pp. 293-318). Palgrave Macmillan, London.

DfID, U. K. (1999). Sustainable livelihoods guidance sheets. London: DFID.

Frank, E. (1999). Rural livelihood diversity in developing countries: evidence and policy implications. Natural Resource perspectives, 40.

Guillotreau, P., Campling, L., \& Robinson, J. (2012). Vulnerability of small island fishery economies to climate and institutional changes. Current Opinion in Environmental Sustainability, 4(3), 287-291.

Hall, A. L., \& Midgley, J. (2004). Social policy for development. Sage.

Kassa, K., \& Eshetu, Z. (2014). Situation analysis of rural livelihoods and socioeconomic dynamics for sustainable rural development: The Case of Legehida Woreda district. Journal of Agriculture and Environmental Management, 3(3), 201-208.

Lélé, S. M. (1991). Sustainable development: a critical review. World development, 19(6), 607-621.

Scoones, I. (2009). Livelihoods perspectives and rural development. The Journal of Peasant Studies, 36(1), 171-196.

Shen, F. (2009). Tourism and the Sustainable Livelihoods Approach: Application Within the Chinese Context: a Thesis Submitted in Partial Fulfilment of the Requirements for the Degree of Doctor of Philosophy at Lincoln University (Doctoral dissertation, Lincoln University).

Sherren, K., Loik, L., \& Debner, J. A. (2016). Climate adaptation in 'new world'cultural landscapes: The case of Bay of Fundy agricultural dykelands (Nova Scotia, Canada). Land use policy, 51, 267-280. 